\title{
Redistribution in Switzerland: Social Cohesion or Simple Smoothing of Lifetime Incomes?
}

\author{
MONiKa Engler ${ }^{a}$
}

JEL-Classification: D31, D91, H22

Keywords: budget incidence analysis, redistribution, lifetime income smoothing, pseudo panel procedure

\section{Introduction}

Over the last few years, the Swiss national budget has steadily increased. In 1990, the expenditures of the state and social security institutions absorbed 40 percent of Switzerland's gross domestic product (GDP); by 2005, this share had risen to 51 percent (compare Table 1). This upsurge can certainly be traced to the slowdown of economic growth. However, it also mirrors the continuous expansion of state activities. The growth of social security and social assistance benefits has been particularly dynamic, but the costs of other sectors, such as higher education $(+78.6$ percent), public transport $(+61.2$ percent $)$, and health services ( +46.6 percent), have risen substantially as well. Against this background, questions arise as to who benefits from the expanding public services and who bears the costs. These questions suggest the more basic question concerning welfare distribution in a state and the overall redistribution that is brought about by public interventions.

In recent years, several analyses have addressed the issue of income distribution and redistribution in Switzerland (ECONOMIESUisse, 2007; KüNZI and Schärrer, 2004; Ecoplan, 2004; Suter and Mathey, 2000). These studies focus on monetary transfers and produced results that are in line with the international literature (AtKinson, Rainwater, and SMEeding, 1995). Taxes, social security contributions, and social benefits reduce income inequalities as they induce redistribution from high-income to low-income segments of the population.

a Swiss Institute for Empirical Economic Research, St.Gallen, Switzerland. I thank Prof. Monika Bütler and Prof. Franz Jaeger for their helpful comments. I am also grateful to the Swiss Federal Statistical Office for granting access to the Survey of Income and Expenditure. 
However, despite the consistent picture that emerges from these analyses, they all have a serious shortcoming: They are limited to monetary and annual transfers. This comes with two important disadvantages. First, real, or in-kind public transfers, such as free education, subsidized health services, and the availability of infrastructure facilities, are ignored and with them a major part of the redistributive volume - real transfers amount to half of the total public spending (see Table 1). An evaluation of the redistributive impact of the state is incomplete without assessing the ways that nonmonetary transfers benefit the different segments of the population.

Second, the exclusive consideration of annual transfers prohibits the consideration of two separate, but conceptually different, redistributive mechanisms. One is the inter-household redistribution across households that have different income levels over the long run. The other mechanism is the intra-household redistribution of income across different phases of life within one household. While the inter-household redistribution aims at a convergence of lifetime income across households, the objective of the intra-household redistribution is to smooth the income over the life cycle. Such smoothing is achieved by shifting the income from one stage of life to the next, primarily from the working stage to the retirement stage. Not distinguishing between these two mechanisms risks overestimating the redistribution across households.

This analysis focuses on these analytical shortcomings and examines the redistributive impact of the state, inclusive of social insurance at the level of individual households. Two sets of questions are examined:

1. What are the redistributive effects of the entire state as well as of individual revenues and expenditures? Who, over the course of a year, benefits from monetary and real public payments and services, and who bears the direct and indirect public costs? And who are the net beneficiaries?

2. To what extent does an annual redistribution involve (a) redistribution across households with different lifetime or long-term income, and (b) redistribution across different phases of life within the same households in order to smooth lifetime income?

Whereas the first set of questions is connected to the first redistribution analysis conducted for Switzerland, undertaken by Leu, Frey, and Buhmann (1988), and aims to update and expand upon those results, the second question addresses a field of research that has been widely neglected in Swiss as well as international literature. The methodological approach is thus twofold. The first step consists of conventional analysis of the annual budget incidence for the years 1990, 1998, 
Table 1: Consolidated Budget of the Confederation, Cantons, Municipalities, and Social Insurance Institutions, 1990, 2000, 2005

\begin{tabular}{|c|c|c|c|c|}
\hline \multirow[t]{2}{*}{ Expenditures (prices 2005) } & \multicolumn{3}{|c|}{ in bn $\mathrm{CHF}$} & \multirow{2}{*}{$\begin{array}{c}\text { change } \\
1990-2005\end{array}$} \\
\hline & 1990 & 2000 & 2005 & \\
\hline General administration & 7.6 & 8.2 & 9.0 & $18.2 \%$ \\
\hline Justice, police, fire brigade & 6.2 & 7.1 & 8.1 & $30.0 \%$ \\
\hline National defence & 8.4 & 5.6 & 4.9 & $-41.7 \%$ \\
\hline International affairs & 2.0 & 2.4 & 2.4 & $22.5 \%$ \\
\hline Regional and district planning & 2.0 & 2.1 & 2.1 & $7.7 \%$ \\
\hline Environment & 2.7 & 2.9 & 2.8 & $2.7 \%$ \\
\hline $\begin{array}{l}\text { Education } \\
\text { State schools, primary education } \\
\text { General education schools, vocational training } \\
\text { University-level institutions }\end{array}$ & $\begin{array}{r}21.1 \\
10.8 \\
6.5 \\
3.8\end{array}$ & $\begin{array}{r}23.8 \\
12.2 \\
6.6 \\
5.0\end{array}$ & $\begin{array}{r}27.4 \\
13.7 \\
7.0 \\
6.7\end{array}$ & $\begin{array}{r}30.2 \% \\
26.5 \% \\
8.1 \% \\
78.6 \%\end{array}$ \\
\hline Culture and recreation & 3.9 & 4.0 & 4.2 & $7.4 \%$ \\
\hline Health & 13.5 & 16.3 & 19.8 & $46.6 \%$ \\
\hline $\begin{array}{l}\text { Transport } \\
\text { Road traffic } \\
\text { Public transport }\end{array}$ & $\begin{array}{r}11.6 \\
6.8 \\
4.8\end{array}$ & $\begin{array}{r}13.6 \\
6.9 \\
6.7\end{array}$ & $\begin{array}{r}14.8 \\
7.1 \\
7.7\end{array}$ & $\begin{array}{r}28.0 \% \\
4.6 \% \\
61.2 \%\end{array}$ \\
\hline $\begin{array}{l}\text { Subsidies } \\
\text { Agriculture } \\
\text { Others }\end{array}$ & $\begin{array}{l}6.5 \\
4.0 \\
2.5\end{array}$ & $\begin{array}{l}7.1 \\
4.4 \\
2.7\end{array}$ & $\begin{array}{l}6.2 \\
4.2 \\
2.0\end{array}$ & $\begin{array}{r}-5.1 \% \\
4.7 \% \\
-21.0 \%\end{array}$ \\
\hline $\begin{array}{l}\text { Payments-out of social insurance (SI) } \\
\text { Old-age insurance (AHV) } \\
\text { Pension plans (BVG; incl. pre-retirem. benefits) } \\
\text { Disability insurance (IV) } \\
\text { Mandat. health ins. (incl. premium reductions) } \\
\text { Unemployment insurance (ALV) } \\
\text { Family and child allowances } \\
\text { Accident insurance (UVG) } \\
\text { Income compensations (EO) } \\
\text { Other expenditures }\end{array}$ & $\begin{array}{r}69.7 \\
24.5 \\
14.4 \\
5.4 \\
9.4 \\
0.5 \\
3.7 \\
3.5 \\
1.1 \\
7.2\end{array}$ & $\begin{array}{r}100.8 \\
30.3 \\
26.3 \\
9.6 \\
13.8 \\
2.9 \\
4.4 \\
4.1 \\
0.7 \\
8.8\end{array}$ & $\begin{array}{r}114.1 \\
32.9 \\
28.2 \\
12.3 \\
17.4 \\
5.8 \\
4.7 \\
4.7 \\
0.8 \\
7.2\end{array}$ & $\begin{array}{r}63.6 \% \\
34.1 \% \\
96.4 \% \\
127.0 \% \\
84.6 \% \\
1040.5 \% \\
27.3 \% \\
35.0 \% \\
-25.2 \% \\
0.4 \%\end{array}$ \\
\hline $\begin{array}{l}\text { Other social welfare } \\
\text { Social assistance } \\
\text { Other benefits of social welfare }\end{array}$ & $\begin{array}{l}5.3 \\
2.6 \\
2.7\end{array}$ & $\begin{array}{l}8.2 \\
5.5 \\
2.8\end{array}$ & $\begin{array}{l}9.3 \\
6.0 \\
3.3\end{array}$ & $\begin{array}{r}73.4 \% \\
130.9 \% \\
18.8 \%\end{array}$ \\
\hline Finance, debt service & 6.9 & 11.3 & 9.5 & $38.3 \%$ \\
\hline $\begin{array}{l}\text { Total expenditures state and SI } \\
\text { In \% of GDP }\end{array}$ & $\begin{array}{l}167.6 \\
40.1 \%\end{array}$ & $\begin{array}{l}213.5 \\
48.5 \%\end{array}$ & $\begin{array}{l}234.8 \\
50.7 \%\end{array}$ & $40.1 \%$ \\
\hline
\end{tabular}


Table 1 continued

\begin{tabular}{|c|c|c|c|c|}
\hline \multirow[t]{2}{*}{ Revenues (prices 2005) } & \multicolumn{3}{|c|}{ in bn $\mathrm{CHF}$} & \multirow{2}{*}{$\begin{array}{c}\text { change } \\
1990-2005\end{array}$} \\
\hline & 1990 & 2000 & 2005 & \\
\hline Taxes on income and property & 54.9 & 64.4 & 67.5 & $22.9 \%$ \\
\hline Income and property taxes & 37.5 & 43.0 & 48.4 & $28.8 \%$ \\
\hline Earnings and capital taxes (corporate taxes) & 9.4 & 13.0 & 12.8 & $35.8 \%$ \\
\hline Withhold. tax, stamp duty (excl. foreign contr.) & 3.9 & 5.6 & 3.5 & $-9.9 \%$ \\
\hline Real estate taxes & 4.1 & 2.8 & 2.9 & $-30.2 \%$ \\
\hline Taxes on property: Tax on motor vehicles & 1.5 & 1.7 & 1.9 & $29.5 \%$ \\
\hline Excise duties & 17.6 & 24.6 & 25.5 & $44.6 \%$ \\
\hline Value-added tax & 12.5 & 17.3 & 18.1 & $45.2 \%$ \\
\hline Mineral oil and fuel taxes & 3.9 & 5.5 & 5.3 & $36.4 \%$ \\
\hline Tax on tobacco products & 1.2 & 1.7 & 2.1 & $64.2 \%$ \\
\hline Vehicle taxes (heavy traffic, nat. routes) & 0.4 & 0.7 & 1.5 & $271.8 \%$ \\
\hline Customs duties & 1.5 & 1.1 & 1.0 & $-35.8 \%$ \\
\hline Royalties and concessions & 1.1 & 1.8 & 1.3 & $15.6 \%$ \\
\hline Other taxes & 2.0 & 1.6 & 1.6 & $-16.3 \%$ \\
\hline Remunerations & 16.2 & 21.9 & 25.0 & $54.0 \%$ \\
\hline Financial and investment income & 6.0 & 14.2 & 13.1 & $117.5 \%$ \\
\hline Payments-in to SI (insurants \& employers) & 69.2 & 83.6 & 94.0 & $35.9 \%$ \\
\hline Old-age/invalidity insurance (AHV/IV), EO & 24.4 & 25.7 & 28.0 & $14.8 \%$ \\
\hline Occupational pension plans (BVG) & 27.7 & 30.8 & 35.8 & $29.3 \%$ \\
\hline Mandatory health insurance & 8.4 & 11.3 & 15.3 & $82.2 \%$ \\
\hline ALV (excl. refunding to border crossers) & 0.8 & 6.5 & 4.3 & $430.2 \%$ \\
\hline Family and child allowances & 3.7 & 4.5 & 4.8 & $29.4 \%$ \\
\hline Accident insurance (UVG) & 4.2 & 4.9 & 5.8 & $38.3 \%$ \\
\hline Capital and other revenues of SI & 16.5 & 20.4 & 17.7 & $6.8 \%$ \\
\hline Occupational benefit institutions & 13.9 & 17.3 & 14.9 & $7.6 \%$ \\
\hline Other SI & 2.7 & 3.1 & 2.7 & $2.6 \%$ \\
\hline Total revenues state and SI & 187.0 & 236.0 & 250.1 & $33.7 \%$ \\
\hline In $\%$ of GDP & $44.7 \%$ & $53.6 \%$ & $54.0 \%$ & \\
\hline Surplus revenue state and SI & 19.4 & 22.5 & 15.3 & \\
\hline Due to state budget & -8.3 & 3.0 & -1.8 & \\
\hline Due to SI budget & 27.2 & 20.0 & 17.5 & \\
\hline
\end{tabular}

Note: Revenues exceed expenditures in the consolidated budget of state and social insurance because the latter records a surplus revenue. The reason for this lies primarily in the second pillar of the 


\section{Table 1 continued}

old-age provision system (occupational pension plans, BVG), which is still in the expansion phase and, therefore, pre-finances future benefits to a higher degree than it pays out in current pensions. Considering the budget without social insurance shows familiar deficits for the years 1990 and 2005 (see the lower three rows in the second part of the table). Abbreviations: SI - social insurance; AHV - Alters-und Hinterlassenenversicherung, old-age and survivors' insurance; ALV - Arbeitslosenversicherung, unemployment insurance; BVG - Berufsvorsorge(gesetz), occupational old-age insurance, i.e. pension plans; EO - Erwerbsersatz(ordnung), income compensations; IV - Invalidenversicherung, disability insurance; UVG -Unfallversicherung, accident insurance. The category 'other taxes' includes inheritance and gift taxes, incentive taxes, beer taxes, lottery taxes, and other property and excise taxes. Sources: Public finance figures (FFA, 1990-2005), Swiss Social Insurance Statistics (FISO, 1990-2005).

and 2000 to 2005 . Secondly, these annual analyses are used to generate a pseudo panel on the basis of which the course of lifetime income before and after public transfers can be constructed. A decomposable inequality measure allows for the separation of inter-household income redistribution from intra-household income shifts over the life cycle.

The results show that the state has a substantial redistributive impact. This impact stems mainly from the public expenditure side, which considerably reduces the income differences in the population. Unlike the implications of short-term effects, however, the convergence of income is not due primarily to the social balancing across households but to the state-prescribed transfers of income across the different stages of life. Income peaks during the working years are broken markedly by an enhanced contribution burden during that period. In return, household income is prevented from declining not only after retirement, but also in times when the labor market or health-related or family-related issues disrupt earning capacity. As a consequence, the variance in lifetime income is clearly reduced.

This paper is structured as follows. The next section discusses the methodological basis, especially the concept of budget incidence analysis, the generation of the pseudo panel using the available data, and the quantification of the inter- and intra-household redistribution via decomposable inequality measures. Section 3 presents the results from an annual and long-term perspective. Section 4 provides guidelines for cautious interpretation. Section 5 summarizes and concludes. 


\section{Methodological Approach and Data}

\subsection{The Concept of Budget Incidence Analysis}

This paper studies redistribution on the basis of budget (or fiscal) incidence analysis. Therefore, first, the pre-fisc income before transfers, i.e., the income that would exist if there were no state and social insurance institutions, is determined for each household. In a second step, the households' post-fisc income is calculated, which is the income that results after taxes and social security contributions (negative transfers), and after the receipt of public services and benefits (positive transfers). The difference between pre- and post-fisc income, i.e. economic situation before and after the allocation of (all or individual) public expenses and revenues allows an estimation of the extent of the (total or intervention-specific) income redistribution.

In this analysis, pre-fisc income is defined as the sum of earned income, capital income, and private transfers before taxes and social security contributions. For homeowners, an imputed rent of the property is added in order to better assess their economic strength compared to that of tenant households. Included as well are implicit taxes that other tax debtors roll off and that lower household income compared to a situation without state intervention. Ranked among such implicit charges are employers' contributions to the social security system that are basically wage components. Depending on the incidence assumptions (see below), corporate taxes are also borne indirectly by private households: If companies distribute profits after taxes, their tax burden eventually falls on wealthy households whose profits per share are diminished.

The computation of post-fisc income involves two steps. The first step is to determine the total size of each transfer category. For this, the annual governmental financial statements (including social insurance institutions, see Table 1) are referenced: The size of the negative and positive transfer categories follow from the positions on the revenue and expenditure sides, respectively. In the second step, the transfer totals are allocated to individual households. The negative transfers are assigned according to the contribution burden borne by the households, and the positive transfers are allocated according to the benefits received by the households. In the case of nonmonetary public services, households are assigned shares of the provision costs according to their service utilization. These shares approximate the amount that the income of the households would have to rise if they had to pay for the public services accessed. ${ }^{1}$

1 More convincing from a theoretical point of view would be the allocation of public services according to a household's willingness to pay and the utility derived from the consumption 
Formally, the estimation of post-fisc income involves

$$
Y_{h, \text { psst-fsc }}=Y_{h, \text { preffisc }}+\sum_{i=1}^{n} S_{i} \frac{U_{i h}}{U_{i}}-\sum_{j=1}^{m} C_{j} \frac{B_{j h}}{B_{j}}
$$

whereby $Y_{b}$ is household income, $S_{i}$ denotes the total transfer size of public service $\mathrm{i}$, and $C_{j}$ the total transfer size of public charge j. $U$ represents utilization and $B$ represents burden. The public services and goods allocated to a household thus depend on its individual utilization (e.g., the number of school days that are provided to its children) compared to the aggregated utilization of the total population (e.g., the total number of school days provided). Accordingly, the charges assigned correspond to the individual burden of a household (e.g., its individual income tax obligation) as compared to the statewide burden (total public revenues from income taxes).

A crucial aspect of budget incidence analyses are the assumptions necessary to allocate the public revenues and expenditures to the individual households. The problem is that only personal taxes, social security contributions, and monetary benefits are directly evident from available data. In contrast, burdens of implicit taxes as well as benefits drawn from in-kind public services must be estimated. This effort requires assumptions as to who, independent of formal tax liability, ultimately finances the state budget, and for whom public services effectively prove advantageous. As far as possible, this analysis adopts the incidence assumptions that are generally accepted in the literature (see BOADWAY and KeEn, 2000; Fullerton and Metcalf, 2002; Ruggeri, 2003). Table 2 shows the standard allocation rules that follow from these assumptions, as well as alternative progressive and regressive scenarios for cases that elicit different views. Detailed explanations are given in the Appendix.

of the services. However, households do not have to reveal such willingness for publicly provided goods (i.e., no price formation takes place). 


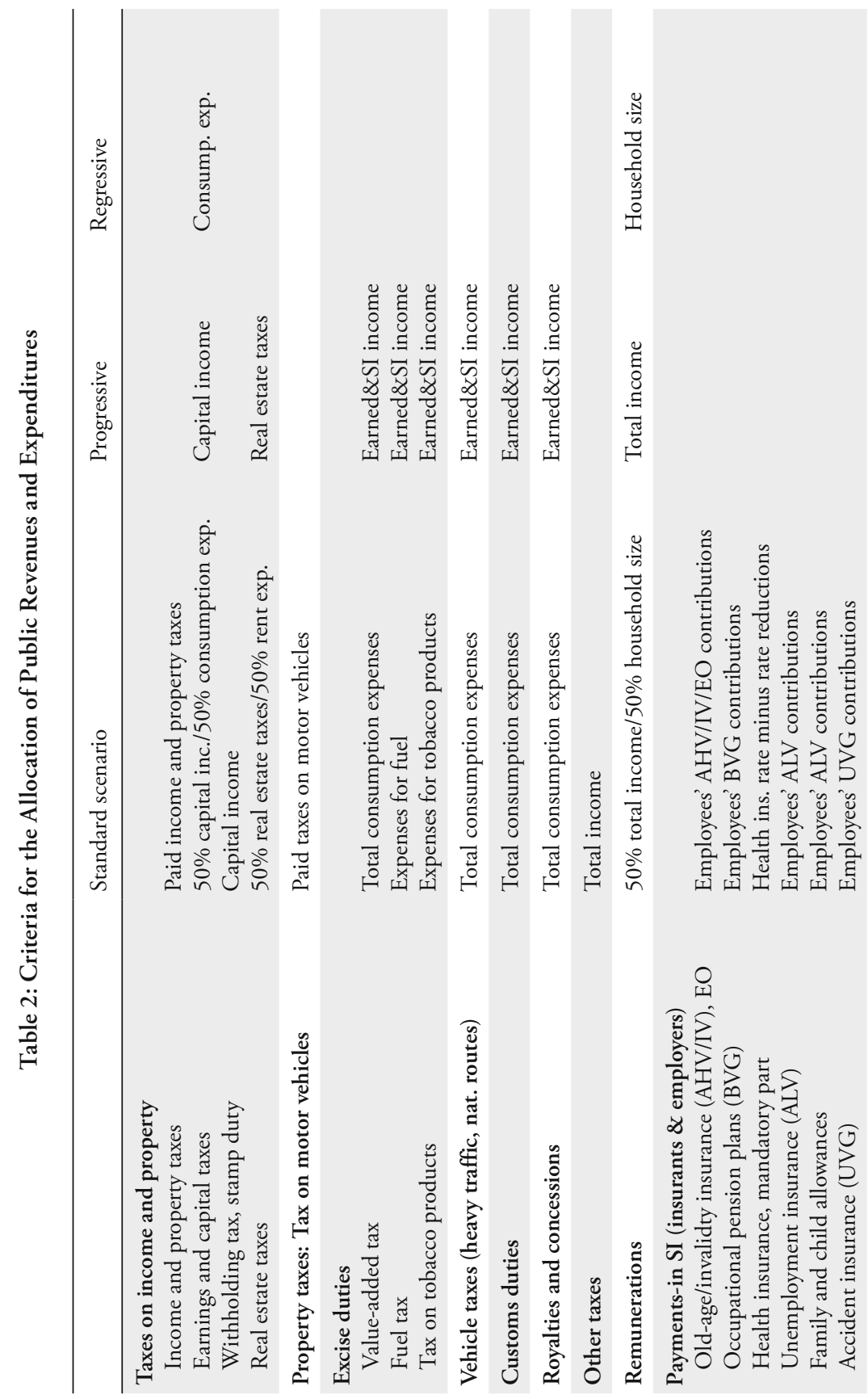




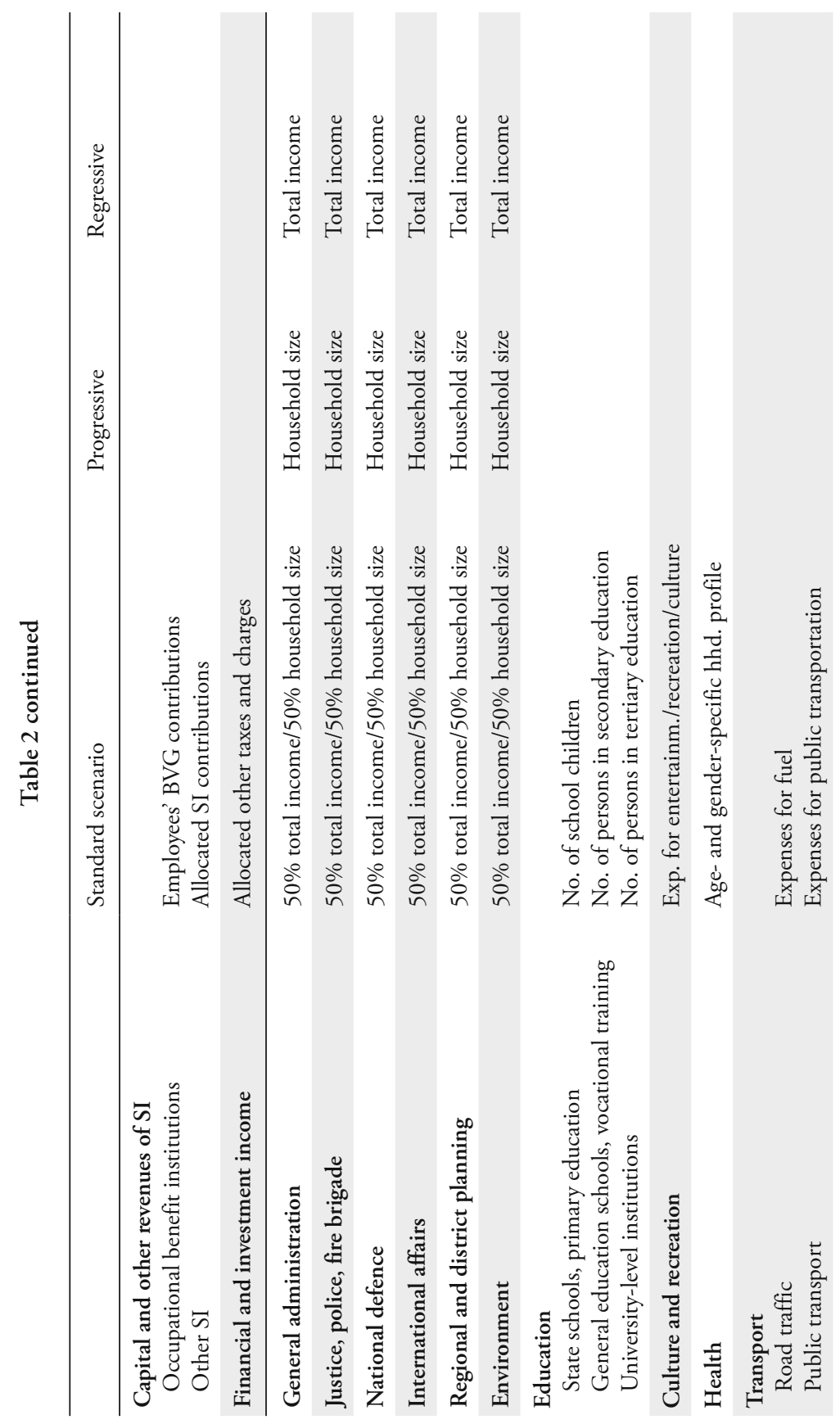




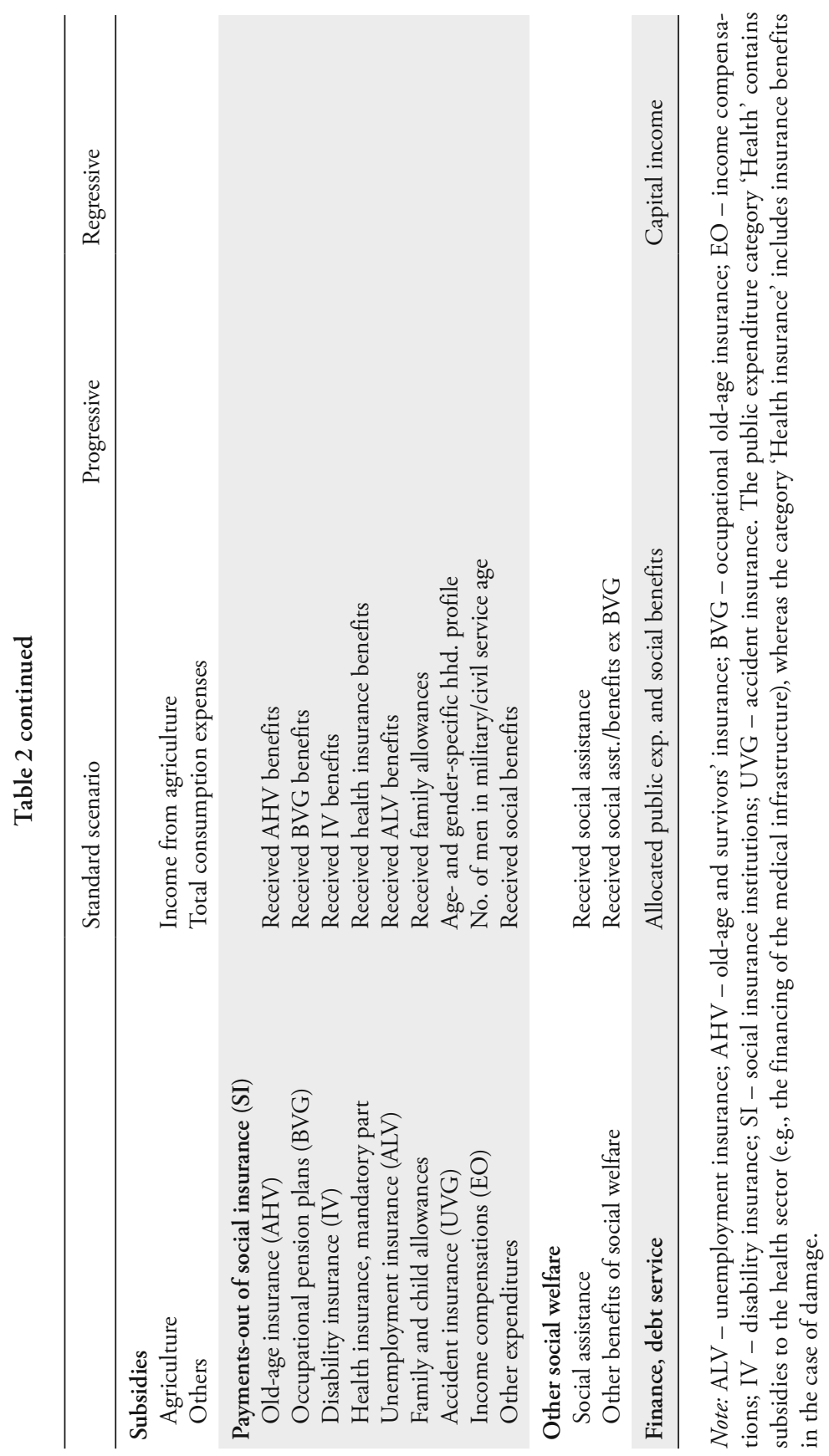




\subsection{Data}

The first database for this study comprises the financial statements of the confederation, the cantons, the municipalities and social insurance institutions; these statements are consolidated to obtain the overall national budget shown in Table 1. The (consolidated) data for the regional corporate bodies are obtained from the Swiss Federal Finance Administration, and those for the social security institutions come from the Federal Social Insurance Office. ${ }^{2}$

The calculation of the pre- and post-fisc household income calls for detailed information about income and expenses, as well as demographic and socioeconomic characteristics, such as age, gender, education, occupation, and employment status, of each household. This information can be extracted from the Survey of Income and Expenditure (SIE; Einkommens- und Verbrauchserhebung), which the Federal Statistical Office conducts yearly and is based on 3000 to 4000 voluntarily participating households. These data contain necessary information both to calculate the pre-fisc income and to assign public revenues and expenditures according to the aforementioned allocation rules. ${ }^{3}$ This study uses the annual SIE survey data collected between 2000 to 2005, as well as data from two earlier surveys conducted in 1990 and 1998.

Available data allows to compute pre- and post-fisc income only on a household level. As households are of different size and composition, this raises the question of inter-household comparability as well as the effective welfare level of the individual household members. The common approach taken to address this issue is the utilization of equivalence scales RUGGerI (2003). This device assigns a weight (equivalence value) to each member in a household according to his or her consumer needs, thereby taking into account that several people living together in a household realize economies of scale. In this study, which uses the OECD equivalence scale, household heads are weighted as 1 , household members above

2 To break down the health sector costs into age- and gender-specific outlays, hospital surveys conducted by the Federal Statistical Office are additionally used.

3 Specifically, for each category of public revenues and expenditures, each household's share in the total of the respective allocation criteria is calculated. This gives distribution keys, which serve to allocate the state budget (scaled down to the SIE sample size) to individual households. In the case of primary education, for instance, nationwide public expenditures of 13.7 billion CHF (year 2005) are scaled down to the population size of the SIE sample of 3044 households or 6986 individuals, which gives 12.8 million CHF. This amount is divided among the SIE households according to the 1333 schoolchildren living in them (= allocation criteria). For example, a household with 2 schoolchildren is allocated 19,200 CHF $(=2 / 1333 * 12.8$ million CHF) of income in the form primary education. 
the age of 15 as 0.5 , and children as $0.3 .{ }^{4}$ Dividing the household income by the sum of these values results in comparable single-person income, that is, income per adult equivalent. This procedure, hence, allows to move back from the preand post-fisc income situation of the household to that of the individual, which, in the end, is the unit of analysis of interest in distributional analyses.

\subsection{Rationale and Construction of the Pseudo Panel}

Similar to previous budget incidence analyses, this work first computes pre- and post-fisc household income on an annual basis. For an appropriate picture of the public redistribution, however, these snapshots must be supplemented by a comparison of long-term income before and after transfers. This requires information on the yearly income of individual households for a long period of time, ideally for a whole life cycle.

Because such panel data, as in most redistribution analyses (see BJÖRKLUND and Palme, 2002, for an exception), is not available, this paper uses the method of pseudo panel construction, developed by Deaton (1985) and BRowning, Deaton, and Irish (1985), to conduct the longitudinal analysis. The idea is that in a series of cross-sectional data, although a household cannot be followed up over time, a cohort, i.e., a clearly distinguishable population segment, such as persons born in the same year, can be tracked. If annual surveys are carried out with a representative selection of the population, the average behavior of a cohort in one period can be related to its average behavior in the next period. Thus, instead of tracking individual households over time, cohorts are observed over time. Given that cohorts are big enough (more than 100 individuals per cohort; see Verbeek and Nijman, 1992), the cohorts' means form a data panel that represents the behavior of the underlying households.

The present work adopts this procedure for the available cross-sectional data sets. In each survey, households are allocated to one of nine cohorts according to the year of birth of the household head $(-1934,1935-1939,1940-44, \ldots, 1970-74)$. The average pre-fisc and post-fisc income per cohort is then combined into a pseudo panel (see Table 10 in the Appendix), which has two uses: First, the pseudo panel serves to simulate a representative life cycle of income before and after transfers.

4 Based on the fact that there is no consensus in the literature on the correct equivalence scale, this study draws on the most widely used scale of the OECD. There are alternative equivalence scales for Switzerland, however, the results depend on the choice of the research instrument, and clear conclusions are difficult to draw (FALTER, 2006). At least, different equivalence scales seem not to be too different for the most common household types. 
Secondly, as discussed in the next section, it allows an estimation of the shares of inter- and intra-household income redistribution in total redistribution.

\subsection{Measurement of Redistribution}

In order to capture the comparisons of the pre- and post-fisc income distributions quantitatively, it is useful to express a given income distribution through a single measure. This task is performed by an inequality measure, which increases in value when a monetary unit flows from a poor household to a rich household. For the purpose of this analysis, a decomposable measure is chosen whereby total inequality in the population can be divided into the inequalities within individual, mutually exclusive groups and into the inequalities across these groups. Cowell (1984) shows that a generalized entropy measure meets these requirements:

$$
I_{\alpha}=\frac{1}{n} \frac{\sum_{i=1}^{n}\left[\left(\frac{y_{i}}{\mu}\right)^{\alpha}-1\right]}{\alpha^{2}-\alpha}
$$

where $y_{i}$ is the income of household $\mathrm{i}, n$ the number of households, and $\mu$ the average income. The parameter $\alpha$ determines if the inequality measure reacts more strongly to inequalities in the upper $(\alpha>0)$ or lower $(\alpha<0)$ income segments. $\alpha$ thus indicates the degree of poverty aversion.

The decomposition is defined as

$$
I_{\alpha}=\sum_{k=1}^{K}\left(\frac{n_{k} \mu_{k}}{n \mu}\right)^{\alpha}\left(\frac{n_{k}}{n}\right)^{1-\alpha} I_{\alpha}^{k}+I_{\alpha}^{B}=I_{\alpha}^{W}+I_{\alpha}^{B}
$$

where $k$ is an index for $K$ mutually exclusive groups, $n_{k}$ denotes the number of households in group $k$, and $\mu_{k}$ is the average income in group $k$. Consequently, $n_{k} \mu_{k} / n \mu$ is the income share of group $k$ in total income, and $n_{k} / n$ its share in total population. $I_{\alpha}^{k}$ denotes the generalized entropy measure within group $k, I_{\alpha}^{W}$ is the weighted average of these group-internal inequality values (within group inequality), and $I_{\alpha}^{B}$ is the generalized entropy measure of the distribution of the group means $\mu_{k}$ (between group inequality).

The decomposition of the inequality measure is used to separate the interhouse-hold from the intra-household redistribution. To this end, total inequality $I_{\alpha}$ is calculated for the pooled sample (all households in all cross-sectional 
data sets) before and after transfers (i.e., $I_{\alpha, p r e-f i s c}$ and $I_{\alpha, p o s t-f i s c}$ ). Then, the cohorts described in the previous section are taken as the mutually exclusive groups. The inequality between these cohorts, $I_{\alpha}^{B}$, is the inequality of the average income that was earned within the individual cohorts from 1990 to 2005. The comparison of the $I_{\alpha}^{B}$ before and after transfers shows which portion of the total redistribution is due to redistribution across cohorts. This comparison indicates the redistribution across households with different long-term income. The residual $I_{\alpha}-I_{\alpha}^{B}=I_{\alpha}^{W}$ shows the inequality within the individual cohorts and represents the income variations over time. The comparison of $I_{\alpha}^{W}$ before and after transfers indicates which shares of the total redistribution are household-internal income shifts across the different stages of life.

\section{Results}

\subsection{Redistribution within a Year: General Overview}

Table 3 compares key figures of pre- and post-fisc income distributions. ${ }^{5}$ It follows that the Swiss state produces considerable redistribution and, in so doing, substantially reduces income inequalities. Through the transfers, the income variance decreases by two-thirds. The smaller difference between the first quintile and the mean indicates that the transfers lessen the right skewness of the income distribution, i.e., the concentration on relatively low income. From the breakdown of income by pre-fisc income deciles, it can be seen that public interventions reduce the income of the upper six deciles, whereas they enhance the income in the lower four deciles. For example, households in the fifth decile with a mean pre-fisc income of 57,900 francs lose 5,400 francs on average, whereas those in the tenth decile forfeit 80,200 francs of their pre-fisc income of 182,000 francs. On the side of the net beneficiaries, on the other hand, the lowest decile gains the most from the state; on average, it receives 67,500 francs.

As Table 3 refers to total (i.e. working and retired) population, the presented figures include old-age pension payments and might be expected to be driven by redistribution across the life cycle within households. Interestingly however, as Table 8 in the Appendix shows, the pattern and dimension of the redistribution persists if only households within working age are considered. This fact indicates that redistribution across households plays its role, too.

5 Results are reported as income per adult equivalent throughout the paper; for details see Section 2.2. 
Table 3: Key Figures of Pre- and Post-Fisc Income Distributions, 2005

\begin{tabular}{|c|c|c|c|c|}
\hline (in $\mathrm{CHF}$ ) & & Pre-fisc income & Post-fisc income & Net transfer \\
\hline Variance & & $3.44 \mathrm{E}+09$ & $1.13 \mathrm{E}+09$ & \\
\hline Mean & & 68,788 & 65,813 & \\
\hline Median & & 62,656 & 59,228 & \\
\hline First quintile & & 20,786 & 44,194 & \\
\hline \multicolumn{5}{|c|}{ Average income per pre-fisc decile } \\
\hline & 1 & 2,500 & 70,000 & 67,500 \\
\hline & 2 & 13,400 & 72,500 & 59,100 \\
\hline & 3 & 30,000 & 61,500 & 31,500 \\
\hline & 4 & 45,800 & 54,900 & 9,100 \\
\hline & 5 & 57,900 & 52,500 & $-5,400$ \\
\hline & 6 & 68,600 & 54,900 & $-13,700$ \\
\hline & 7 & 80,500 & 57,600 & $-22,900$ \\
\hline & 8 & 93,700 & 64,600 & $-29,100$ \\
\hline & 9 & 113,900 & 68,000 & $-45,900$ \\
\hline & 10 & 182,000 & 101,800 & $-80,200$ \\
\hline
\end{tabular}

Note: The reduction of mean income through transfers is due to the fact that the consolidated state and social insurance budget is allocated to households. As mentioned, the social insurance sector accounts for a surplus revenue because of the occupational pension system that is still in the expansion phase. Consequently, more public revenues than expenditures are assigned to households, thus leading to a negative average net transfer.

Figure 1 illustrates the redistribution by means of Lorenz curves. The solid curves represent the ordinary Lorenz curves before and after transfers and show the income shares that fall to different population shares. The 45 degree line serves as a reference and represents the equal distribution of income. Due to the transfers, the Lorenz curve moves closer to the 45 degree line, which points out the reduction in income inequalities. For instance, in the absence of state interventions, the 20 percent poorest households together would receive barely 3 percent of the total income, whereas the 20 percent poorest households in the present situation actually receive 12 percent of the total income.

Particularly interesting is a 'modified' Lorenz curve in the form of a concentration curve. This curve shows the proportion of total post-fisc income that 
Figure 1: Lorenz Curves for Pre- and Post-Fisc Income, 2005

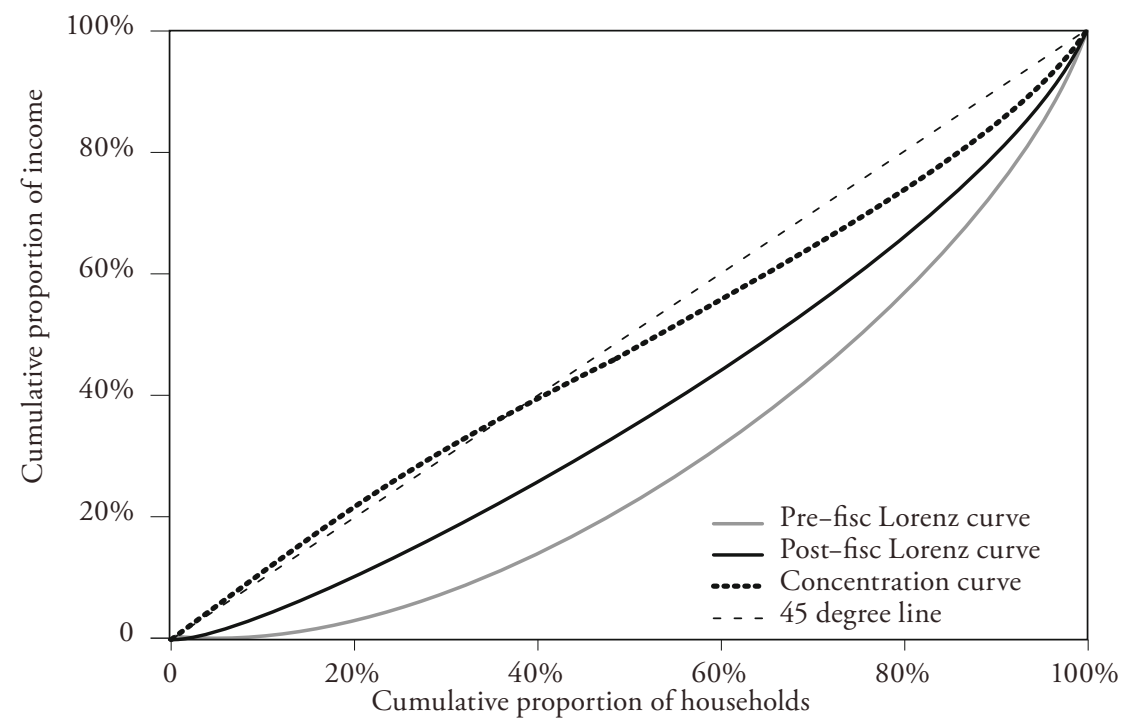

Note: The pre-fisc and post-fisc Lorenz curves show, respectively, which proportions of the (prefisc or post-fisc) income fall upon different households shares for households that are ordered according to pre-fisc and post-fisc income. The concentration curve maintains the order of the households according to pre-fisc income and shows which proportion of post-fisc income falls upon the households.

falls upon the households, which are ordered by increasing pre-fisc income (as opposed to increasing post-fisc income, as is the case of the ordinary post-fisc Lorenz curve). The concentration curve indicates that the poorest 40 percent of households, as measured by pre-fisc income, receive only about 13 percent of the total income before transfers, but 40 percent of the total income after transfers. This distribution suggests that for low-income groups, state interventions even lead to an elimination of income inequalities.

\subsection{Incidence of Individual Public Interventions}

Table 4 shows, per income quintile, the benefits and burdens that accrue to an average household from the public expenditures and revenues, respectively. If the expenditure side and the absolute values are considered first, it is seen (beginning of Table 4) that public spending favors households with the lowest 
Table 4: Incidence of Public Expenditures and Revenues by Quintile of Pre-Fisc Household Income, 2005

\begin{tabular}{|c|c|c|c|c|c|c|}
\hline & Q1 & Q2 & Q3 & Q4 & Q5 & Mean \\
\hline & \multicolumn{6}{|c|}{ per adult equivalent, in $\mathrm{CHF}$} \\
\hline Pre-fisc income & $\begin{array}{l}7,940 \\
(6,380)\end{array}$ & $\begin{array}{r}37,880 \\
(9,190)\end{array}$ & $\begin{array}{r}63,220 \\
(6,300)\end{array}$ & $\begin{array}{r}87,090 \\
(7,680)\end{array}$ & $\begin{array}{r}147,930 \\
(75,620)\end{array}$ & $\begin{array}{l}68,790 \\
(58,670)\end{array}$ \\
\hline Public spending & 88,000 & 51,960 & 32,160 & 29,610 & 30,690 & 46,490 \\
\hline Public goods & 4,320 & 5,030 & 5,490 & 5,970 & 7,860 & 5,730 \\
\hline Education & 2,100 & 7,460 & 6,570 & 5,510 & 3,310 & 4,990 \\
\hline Culture & 600 & 620 & 740 & 980 & 1,370 & 860 \\
\hline Health & 6,390 & 3,710 & 2,920 & 2,740 & 2,930 & 3,740 \\
\hline Transport & 2,210 & 2,280 & 2,810 & 3,060 & 4,370 & 2,950 \\
\hline Subsidies & 560 & 2,380 & 950 & 420 & 970 & 1,050 \\
\hline Old-age insurance (AHV) benefits & 24,750 & 5,890 & 900 & 710 & 1,140 & 6,680 \\
\hline Pension plan benefits (BVG) & 19,940 & 7,600 & 1,440 & 1,420 & 1,090 & 6,300 \\
\hline Disability insurance (IV) benefits & 4,670 & 4,410 & 1,890 & 1,170 & 540 & 2,540 \\
\hline Health insurance benefits & 3,750 & 3,390 & 3,190 & 3,260 & 3,300 & 3,380 \\
\hline Other social insurance benefits & 9,930 & 6,080 & 3,880 & 2,870 & 2,530 & 5,060 \\
\hline Social assistance & 6,990 & 1,780 & 310 & 460 & 150 & 1,940 \\
\hline Debt service & 3,570 & 2,110 & 1,300 & 1,200 & 1,250 & 1,890 \\
\hline Public revenues & 24,720 & 31,660 & 41,670 & 55,600 & 93,740 & 49,460 \\
\hline Income and property taxes & 6,460 & 5,570 & 6,110 & 9,280 & 20,710 & 9,620 \\
\hline Earnings and capital taxes & 2,010 & 2,370 & 1,700 & 2,040 & 4,710 & 2,560 \\
\hline Excise duties & 4,020 & 3,980 & 4,660 & 5,440 & 7,250 & 5,070 \\
\hline Other taxes & 2,290 & 2,340 & 2,110 & 2,560 & 4,460 & 2,750 \\
\hline Remunerations & 3,680 & 4,280 & 4,670 & 5,090 & 6,690 & 4,880 \\
\hline Public investments & 1,930 & 1,940 & 2,010 & 2,550 & 4,570 & 2,600 \\
\hline Contributions to AHV and IV & 810 & 3,050 & 5,290 & 7,030 & 11,020 & 5,440 \\
\hline Contributions to pension plans & 70 & 2,510 & 6,170 & 9,710 & 17,300 & 7,150 \\
\hline Contributions to health insurance & 3,170 & 2,820 & 2,870 & 2,980 & 3,050 & 2,980 \\
\hline $\begin{array}{l}\text { Contributions to other social } \\
\text { insurance }\end{array}$ & 130 & 1,470 & 3,010 & 4,180 & 5,680 & 2,890 \\
\hline Capital income of social insurance & 150 & 1,330 & 3,070 & 4,750 & 8,290 & 3,520 \\
\hline
\end{tabular}


Table 4 continued

\begin{tabular}{|c|c|c|c|c|c|c|}
\hline & Q1 & Q2 & Q3 & Q4 & Q5 & Mean \\
\hline & \multicolumn{6}{|c|}{ in $\%$ of pre-fisc income } \\
\hline Pre-fisc income & 100.0 & 100.0 & 100.0 & 100.0 & 100.0 & 100.0 \\
\hline Public spending & 1108.3 & 137.2 & 50.9 & 34.0 & 20.7 & 67.6 \\
\hline Public goods & 54.4 & 13.3 & 8.7 & 6.9 & 5.3 & 8.3 \\
\hline Education & 26.4 & 19.7 & 10.4 & 6.3 & 2.2 & 7.3 \\
\hline Culture & 7.6 & 1.6 & 1.2 & 1.1 & 0.9 & 1.3 \\
\hline Health & 80.4 & 9.8 & 4.6 & 3.1 & 2.0 & 5.4 \\
\hline Transport & 27.9 & 6.0 & 4.5 & 3.5 & 3.0 & 4.3 \\
\hline Subsidies & 7.0 & 6.3 & 1.5 & 0.5 & 0.7 & 1.5 \\
\hline Old-age insurance (AHV) benefits & 311.7 & 15.6 & 1.4 & 0.8 & 0.8 & 9.7 \\
\hline Pension plan benefits (BVG) & 251.1 & 20.1 & 2.3 & 1.6 & 0.7 & 9.2 \\
\hline Disability insurance (IV) benefits & 58.8 & 11.6 & 3.0 & 1.3 & 0.4 & 3.7 \\
\hline Health insurance benefits & 47.3 & 9.0 & 5.0 & 3.7 & 2.2 & 4.9 \\
\hline Other social insurance benefits & 125.0 & 16.0 & 6.1 & 3.3 & 1.7 & 7.4 \\
\hline Social assistance & 88.0 & 4.7 & 0.5 & 0.5 & 0.1 & 2.8 \\
\hline \multirow[t]{2}{*}{ Debt service } & 45.0 & 5.6 & 2.1 & 1.4 & 0.8 & 2.7 \\
\hline & \multicolumn{6}{|c|}{ in $\%$ of pre-fisc income + benefits (real and monetary) } \\
\hline Public revenues & 25.8 & 35.2 & 43.7 & 47.6 & 52.5 & 42.9 \\
\hline Income and property taxes & 6.7 & 6.2 & 6.4 & 8.0 & 11.6 & 8.3 \\
\hline Earnings and capital taxes & 2.1 & 2.6 & 1.8 & 1.7 & 2.6 & 2.2 \\
\hline Excise duties & 4.2 & 4.4 & 4.9 & 4.7 & 4.1 & 4.4 \\
\hline Other taxes & 2.4 & 2.6 & 2.2 & 2.2 & 2.5 & 2.4 \\
\hline Remunerations & 3.8 & 4.8 & 4.9 & 4.4 & 3.7 & 4.2 \\
\hline Public investments & 2.0 & 2.2 & 2.1 & 2.2 & 2.6 & 2.3 \\
\hline Contributions to AHV and IV & 0.8 & 3.4 & 5.5 & 6.0 & 6.2 & 4.7 \\
\hline Contributions to pension plans & 0.1 & 2.8 & 6.5 & 8.3 & 9.7 & 6.2 \\
\hline Contributions to health insurance & 3.3 & 3.1 & 3.0 & 2.6 & 1.7 & 2.6 \\
\hline $\begin{array}{l}\text { Contributions to other social } \\
\text { insurance }\end{array}$ & 0.1 & 1.6 & 3.2 & 3.6 & 3.2 & 2.5 \\
\hline Capital income of social insurance & 0.2 & 1.5 & 3.2 & 4.1 & 4.6 & 3.1 \\
\hline
\end{tabular}




\section{Table 4 continued}

Note: The allocation of public expenditures and revenues to households is based on the incidence assumptions of the standard scenario defined in Table 2. Q1 to Q5 denote the quintiles of the pre-fisc household income distribution. The expenditure category 'public goods' combines the subcategories of general administration, justice, police, national defence, international affairs, regional planning, and environment. 'Other social insurance' includes unemployment insurance, family and child allowances, accident insurance and income compensation. 'Excise duties' includes value-added taxes, mineral oil and fuel taxes, and taxes on tobacco products. The category 'other taxes' includes withholding taxes, stamp duties, real estate taxes, taxes on motor vehicles, customs duties, royalties and concessions, inheritance and gift taxes, incentive taxes, and other property and excise taxes. Figures in parentheses are standard errors.

pre-fisc income most and decreases this favoritism with increasing income. The combined benefits for the first quintile sum up to 88,000 francs on average and are thus almost twice as high as the benefits to the average household. The benefits for the second quintile with 51,960 francs are still 12 percent above the average. The households in the third to fifth quintiles each receive about 30,000 francs from public expenditures, which is about one-third below the average gain.

The breakdown of expenditures into individual parts shows that the provision of general public goods, the expenditures for individual and for public transport, as well as subsidization of culture resources, reaches high-income households to a greater extent than it reaches low-income households. In the case of public goods, this finding expresses the assumption of the standard incidence scenario, wherein households with high income and wealth benefit more from a favorable (business) environment created, for example, by an efficient public administration, a functioning legal system, or good foreign relations. In the case of transportation infrastructure and cultural subsidies, well-off households profit more than low-income households because they are better able to afford the private outlays necessary to make use of the public services.

In contrast, public spending for the health sector as well as for social security transfers is concentrated in low-income households. As indicated by the benefits of the old-age provisions (AHV and BVG), the state effectively protects income during times when earning ability is no longer feasible. In the first quintile, which consists mainly of retired households, old-age benefits boost income by almost 45,000 francs. In the second quintile, the remittances still amount to 13,000 francs and can be traced back largely to partly retired households. For the upper 
income quintiles, which contain only a few pensioner households, the AHV and BVG benefits are small and explained mainly by widows' pensions, children's allowances, and disability benefits from occupational pension plans. In the case of public health expenditures, the relatively high support of the first quintile reflects the higher utilization of health care services by the elderly.

The other social security transfers also tend to benefit the lowest two quintiles, but reach the middle- and high-income groups as well. This finding reflects compensations for temporary disruptions in the ability to work, such as illness, unemployment, or maternity. Finally, expenditures to service the public debt appear in favor of the low-income groups. This finding is in accordance with the incidence assumption that groups who receive most from the state are also those who contribute most to the spending deficit.

On the public revenue side, payments to the state increase with income (Table 4, bottom of p. 123). Whereas the representative household of the first quintile with 24,720 francs contributes only half as much as the average household, the household in the fifth quintile with 93,740 pays 1.9 times as much. This inequality in the burden is still more pronounced for social security contributions from which the (often retired) households in the first quintile are practically exempt. Only health insurance premiums are on a similar level of about 3,000 francs in all income categories.

The situation is different for taxes. The first quintile does not bear the least burden; instead, it is the second or third quintile. The reason for this situation lies again in the fact that the first quintile contains mainly households whose income is derived primarily from social transfers. Because such income is taxable, the income taxes are relatively high in comparison to the pre-fisc income. Moreover, for the often wealthy pensioner households, property taxes, as well as the earnings and capital tax of the business sector, carry weight, half of which is shifted to the capital owners in the standard scenario.

\subsection{Vertical Redistribution: Relative Incidence of Public Interventions}

Having analyzed the incidences in absolute values, the question remains as to the conclusions that can be drawn with regard to the redistributive effects. Top-down or progressive redistribution takes place when the financially weak improve their position vis-a-vis the financially strong. On the expenditure side, this means that poor households must receive more benefits relative to their pre-fisc income. If low-income households receive smaller benefits in absolute terms, a public intervention can thus still work progressively as long as the poor receive more benefits relative to their pre-fisc income. On the side of public revenues, a contribution is 
progressive if poor households pay less than rich ones, not only in absolute terms but also in relation to pre-fisc income.

At the top of p. 124, Table 4, shows the public expenditures per household in terms of percentage of the pre-fisc income for each quintile. The table shows that the lowest income quintile receives public benefits that, on average, multiply the pre-fisc income by a factor of eleven. Meanwhile, the topmost quintile at the other end of the spectrum increases its income by just 20.7 percent. As indicated by the detailed figures, the social benefits work progressively, and, to a lesser extent, the rest of the public spending does, too. Although well-off households in part receive more in francs, they benefit less than low-income households in terms of the proportion of their pre-fisc income. For example, cultural subsidies, where the absolute values are the most widespread, household income increases by 7.6 percent in the first quintile, but only by 0.9 percent in the fifth quintile.

In the last part of Table 4, household contribution burdens are related to the household's economic strength. Note that, deviating from the public expenditure side, pre-fisc income plus real and monetary benefits received from the state are used as the reference base. This approach takes into account that the tax requirements depend on the economic capacity after the receipt of the positive transfers. With this broader reference base, the contribution system as a whole shows to be progressive. The first income quintile with an average contribution rate of 25.8 percent pays half as much as the highest quintile. If only taxes are considered, the detailed figures reveal that, at best, income and property taxes have a progressive effect, however. There, the lower three quintiles remit taxes in the amount of 6 to 7 percent of the sum of the pre-fisc income and benefits, whereas the fourth and fifth quintiles pay 8.0 and 11.6 percent, respectively. The other taxes do not show a lower charge for the less well-off households; their effect is rather neutral to regressive. In contrast, the social contributions, apart from health insurance, appear to have a progressive effect.

These findings are largely confirmed when examined for their statistical significance. This paper uses a nonparametric bootstrap procedure to test $\Delta I_{\alpha}=I_{\alpha, p r e-f i s c}-I_{\alpha, \text { pst-fisc }}$, as defined in Section 2.4, for a significant deviance from zero. The results (see Table 9 in the Appendix) confirm the impression that the monetary social benefits induce the strongest top-down redistribution. Second are the real public benefits. In case of the taxes, the tests show that the tax system as a whole hardly generates redistributive effects. The significant progressivity of the income and property taxes is absorbed by the inverse redistributive effects of the other taxes, above all the regressive excise taxes. The only test results that are contrary to the findings above are those for the social contributions. Instead of 
having a leveling progressive effect, social contributions show to increase income inequality. ${ }^{6}$

\subsection{Redistribution across Socioeconomic Groups}

The results presented so far have focused on the vertical redistribution across income groups. This section aims to give an indication of the horizontal redistribution across socioeconomic groups. The incidence results shown in Table 4 already have revealed the redistribution from working to retired households. Now, for the working-age population, the following examines to what extent the state brings about (1) redistribution between childless households and families with children, and (2) redistribution across households with different work loads.

Table 5 presents the expenditure and revenue incidence for different types of households. It shows that couples without children (school age or in education) realize the highest pre-fisc income. With 96,070 francs per adult equivalent, this group lies about 20 percent above the average pre-fisc income of nearly 80,000 francs. The second highest income earners are couples with one child as well as single-person households. With an increase in the number of children, the prefisc income declines, whereby the income losses are greater with the first and second child than with subsequent children. This finding reflects the frequent withdrawal from work by mothers after the birth of the first child or, at the latest, second child. Consequently, households with more than one child generate below-average pre-fisc income. However, income before transfers are by far the lowest for single-parent households. With 51,930 francs they earn about 35 percent less than average.

State transfers smooth the income distribution in favor of families with children. Although childless couples still derive the highest income, their lead over the average household falls to 8 percent. Even greater is the loss for single-person households whose post-fisc income is below average. In contrast, couples with more than one child slightly benefit as their income approaches the average from below. By far the most favored group is single-parent households, however.

6 Detailed tests reveal that income-indifferent health insurance premiums play a part in this finding; however, when they are excluded, regressive effects still remain in the middle and upper income groups. More important are the comparatively high contributions of the (upper) middle class to pension funds. These households have a greater propensity to save within occupational provision plans than do the highest income households. As a consequence, payments to pension funds (direct and indirect ones in the form of capital gains of the pension funds) lose their leveling effect in the upper part of the income distribution. 
Table 5: Incidence of Public Expenditures and Revenues by Type of Household, Households in Working Age Group, 2005

\begin{tabular}{|c|c|c|c|c|c|c|c|}
\hline & 紊 & 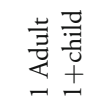 & $\frac{u}{\tilde{\Xi}}$ & 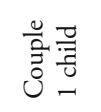 & 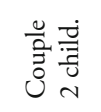 & 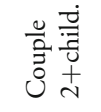 & 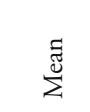 \\
\hline & \multicolumn{7}{|c|}{ per adult equivalent, in $\mathrm{CHF}$} \\
\hline Pre-fisc income & $\begin{array}{l}83,010 \\
(75,930)\end{array}$ & $\begin{array}{l}51,930 \\
(38,640)\end{array}$ & $\begin{array}{l}96,070 \\
(57,150)\end{array}$ & $\begin{array}{l}83,770 \\
(57,330)\end{array}$ & $\begin{array}{l}69,300 \\
(33,630)\end{array}$ & $\begin{array}{l}60,520 \\
(31,240)\end{array}$ & $\begin{array}{l}79,790 \\
(57,150)\end{array}$ \\
\hline Post-fisc income & $\begin{array}{l}61,660 \\
(38,680)\end{array}$ & $\begin{array}{l}65,570 \\
(34,330)\end{array}$ & $\begin{array}{l}68,690 \\
(31,570)\end{array}$ & $\begin{array}{l}64,670 \\
(40,610)\end{array}$ & $\begin{array}{l}59,420 \\
(25,220)\end{array}$ & $\begin{array}{l}59,140 \\
(24,790)\end{array}$ & $\begin{array}{l}63,650 \\
(33,270)\end{array}$ \\
\hline Public spending & 33,360 & 46,340 & 37,730 & 36,010 & 35,480 & 39,190 & 36,870 \\
\hline Public goods & 5,250 & 5,370 & 6,340 & 6,330 & 6,200 & 6,250 & 5,970 \\
\hline Education, primary & 0 & 6,390 & 0 & 3,700 & 7,460 & 10,300 & 3,180 \\
\hline Education, secondary & 1,040 & 4,560 & 920 & 1,570 & 1,770 & 2,150 & 1,500 \\
\hline Education, tertiary & 1,830 & 2,380 & 1,270 & 1,210 & 1,090 & 570 & 1,410 \\
\hline Culture & 930 & 780 & 1,000 & 940 & 800 & 720 & 890 \\
\hline Health & 2,110 & 2,710 & 3,000 & 2,940 & 3,020 & 3,110 & 2,800 \\
\hline Transport & 3,530 & 2,460 & 3,460 & 3,050 & 2,410 & 2,320 & 3,060 \\
\hline Subsidies & 760 & 750 & 1,080 & 1,290 & 1,260 & 2,900 & 1,220 \\
\hline $\begin{array}{l}\text { Old-age ins. (AHV)/pension } \\
\text { plans }\end{array}$ & 3,210 & 610 & 6,820 & 1,410 & 200 & 40 & 2,990 \\
\hline $\begin{array}{l}\text { Disability insurance (IV) } \\
\text { benefits }\end{array}$ & 4,700 & 5,990 & 3,430 & 1,420 & 1,000 & 810 & 3,120 \\
\hline Health insurance benefits & 2,780 & 3,010 & 3,650 & 3,570 & 3,260 & 3,020 & 3,270 \\
\hline Other social insurance benefits & 4,530 & 5,420 & 3,970 & 5,370 & 4,560 & 4,890 & 4,590 \\
\hline Social assistance & 1,850 & 4,650 & 1,640 & 1,900 & 1,120 & 620 & 1,710 \\
\hline Debt service & 1,350 & 1,880 & 1,530 & 1,460 & 1,440 & 1,590 & 1,500 \\
\hline Public revenues & 54,710 & 32,690 & 65,120 & 55,100 & 45,360 & 40,570 & 53,020 \\
\hline Income and property taxes & 10,610 & 4,730 & 12,950 & 9,870 & 6,910 & 5,880 & 9,620 \\
\hline Earnings and capital taxes & 2,310 & 1,420 & 2,460 & 1,820 & 1,520 & 1,270 & 1,990 \\
\hline Excise duties & 6,030 & 4,540 & 6,080 & 5,070 & 4,360 & 3,850 & 5,290 \\
\hline Other taxes & 2,790 & 1,810 & 2,910 & 2,330 & 2,010 & 1,670 & 2,450 \\
\hline Remunerations & 4,470 & 4,570 & 5,400 & 5,390 & 5,280 & 5,330 & 5,090 \\
\hline Public investments & 2,740 & 1,780 & 3,110 & 2,560 & 2,100 & 1,880 & 2,550 \\
\hline
\end{tabular}


Table 5 continued

\begin{tabular}{|c|c|c|c|c|c|c|c|}
\hline & 莺 & 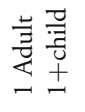 & $\frac{0}{\tilde{0}}$ & 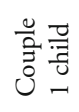 & 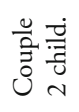 & 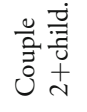 & $\sum_{\substack{\tilde{\Sigma} \\
\Sigma}}$ \\
\hline Contributions to AHV and IV & 6,690 & 3,430 & 8,140 & 6,970 & 5,830 & 5,230 & 6,600 \\
\hline Contributions to pension plans & 8,690 & 3,990 & 11,030 & 9,490 & 7,640 & 7,040 & 8,730 \\
\hline Contributions to health ins. & 2,470 & 2,420 & 3,330 & 3,200 & 2,830 & 2,490 & 2,890 \\
\hline Contrib. to other social ins. & 3,670 & 1,990 & 4,330 & 3,760 & 3,130 & 2,490 & 3,550 \\
\hline Capital income of social ins. & 4,250 & 2,010 & 5,380 & 4,640 & 3,750 & 3,440 & 4,270 \\
\hline
\end{tabular}

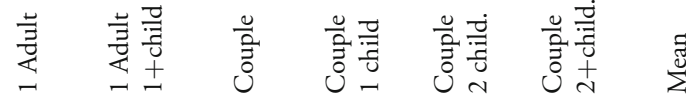

\begin{tabular}{lrrrrrrr}
\hline & \multicolumn{7}{c}{ in \% of pre-fisc income } \\
\hline Pre-fisc income & 100.0 & 100.0 & 100.0 & 100.0 & 100.0 & 100.0 & 100.0 \\
\hline Post-fisc income & 74.3 & 126.3 & 71.5 & 77.2 & 85.7 & 97.7 & 79.8 \\
\hline Public spending & 40.2 & 89.2 & 39.3 & 43.0 & 51.2 & 64.8 & 46.2 \\
\hline Public goods & 6.3 & 10.3 & 6.6 & 7.6 & 8.9 & 10.3 & 7.5 \\
\hline Education, primary & 0.0 & 12.3 & 0.0 & 4.4 & 10.8 & 17.0 & 4.0 \\
Education, secondary & 1.2 & 8.8 & 1.0 & 1.9 & 2.6 & 3.5 & 1.9 \\
Education, tertiary & 2.2 & 4.6 & 1.3 & 1.4 & 1.6 & 0.9 & 1.8 \\
Culture & 1.1 & 1.5 & 1.0 & 1.1 & 1.1 & 1.2 & 1.1 \\
\hline Health & 2.5 & 5.2 & 3.1 & 3.5 & 4.4 & 5.1 & 3.5 \\
Transport & 4.2 & 4.7 & 3.6 & 3.6 & 3.5 & 3.8 & 3.8 \\
\hline Subsidies & 0.9 & 1.5 & 1.1 & 1.5 & 1.8 & 4.8 & 1.5 \\
\hline Old-age ins. (AHV)/pension & 3.9 & 1.2 & 7.1 & 1.7 & 0.3 & 0.1 & 3.8 \\
plans & & & & & & & \\
\hline $\begin{array}{l}\text { Disability insurance (IV) } \\
\text { benefits }\end{array}$ & 5.7 & 11.5 & 3.6 & 1.7 & 1.4 & 1.3 & 3.9 \\
\hline Health insurance benefits & 3.3 & 5.8 & 3.8 & 4.3 & 4.7 & 5.0 & 4.1 \\
\hline Other social insurance benefits & 5.5 & 10.4 & 4.1 & 6.4 & 6.6 & 8.1 & 5.8 \\
\hline Social assistance & 2.2 & 9.0 & 1.7 & 2.3 & 1.6 & 1.0 & 2.1 \\
\hline Debt service & 1.6 & 3.6 & 1.6 & 1.7 & 2.1 & 2.6 & 1.9 \\
\hline & & & & & & & \\
\hline
\end{tabular}


Table 5 continued

\begin{tabular}{|c|c|c|c|c|c|c|c|}
\hline & 売 & 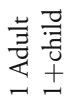 & $\frac{\stackrel{0}{0}}{\stackrel{\Xi}{\Xi}}$ & 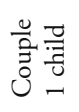 & 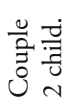 & 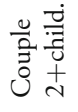 & 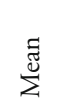 \\
\hline & \multicolumn{7}{|c|}{ in $\%$ of pre-fisc income + benefits (real \& monetary) } \\
\hline Public revenues & 47.0 & 33.3 & 48.7 & 46.0 & 43.3 & 40.7 & 45.4 \\
\hline Income and property taxes & 9.1 & 4.8 & 9.7 & 8.2 & 6.6 & 5.9 & 8.2 \\
\hline Earnings and capital taxes & 2.0 & 1.4 & 1.8 & 1.5 & 1.4 & 1.3 & 1.7 \\
\hline Excise duties & 5.2 & 4.6 & 4.5 & 4.2 & 4.2 & 3.9 & 4.5 \\
\hline Other taxes & 2.4 & 1.8 & 2.2 & 1.9 & 1.9 & 1.7 & 2.1 \\
\hline Remunerations & 3.8 & 4.7 & 4.0 & 4.5 & 5.0 & 5.3 & 4.4 \\
\hline Public investments & 2.4 & 1.8 & 2.3 & 2.1 & 2.0 & 1.9 & 2.2 \\
\hline Contributions to AHV and IV & 5.7 & 3.5 & 6.1 & 5.8 & 5.6 & 5.2 & 5.7 \\
\hline Contributions to pension plans & 7.5 & 4.1 & 8.2 & 7.9 & 7.3 & 7.1 & 7.5 \\
\hline Contributions to health ins. & 2.1 & 2.5 & 2.5 & 2.7 & 2.7 & 2.5 & 2.5 \\
\hline Contrib. to other social ins. & 3.2 & 2.0 & 3.2 & 3.1 & 3.0 & 2.5 & 3.0 \\
\hline Capital income of social ins. & 3.7 & 2.0 & 4.0 & 3.9 & 3.6 & 3.4 & 3.7 \\
\hline
\end{tabular}

Note: The allocation of public expenditures and revenues to households corresponds to the incidence assumptions of the standard scenario defined in Section 2 and Table 2. Figures in parentheses are standard errors.

With a post-fisc income of 65,570 francs, they not only receive an above average income, but are also the only household type that is better off in comparison to its pre-fisc situation. As observed from the second half of Table 5, the resource endowment of single-parent households increases by 26 percent.

Interventions that lead to redistribution towards households with children can be found in both public expenditures and revenues. On the expenditure side, the provision of free primary education is at the fore and, to a lesser extent, secondary and vocational education. Higher education, in contrast, often benefits childless couples as well. Disability insurance, besides supporting households without children, of which there are many in the advanced working age group, favors single parents. Other forms of social insurance and social assistance strongly target single parents, too. This finding comes to light particularly if the benefits are 
related to pre-fisc income (second half of Table 5). On the public revenue side, family households, in terms of absolute value as well as in relation to pre-fisc income, bear the lowest tax burden. The same is true for social security contributions, with the exception of health insurance premiums. Again, single-parent households are afforded the most tax relief.

Table 6 shows the expenditure and revenue incidence for working-age households with a full-time ( $>90 \%)$, middle (50-90\%) and small (<50\%) work load, without and with school-age children up to 16 years. One hundred percent is defined as a work week with 40 hours. A household falls into the full-time category if the average work time of all household members above 18 - thus including possible adult children still living in the parents' house - is at least 36 hours. Accordingly, households in which the adults work on average 20 to 36 hours (less than 20 hours) per week are classified in the middle (small) category.

For childless households, pre-fisc income rises with the number of work hours. In contrast, for households with children, pre-fisc income hardly differs between those with full-time and middle work hours; only households working less than 50 percent clearly earn less. This finding indicates that there are low market income and relatively big families among households with long work hours. As the sizeable inflow of subsidies into the ' $>90 \%$, w. child' category shows, this trend is driven partly by farming households.

With respect to different work loads in the labor market as well, the analysis indicates that public transfers smooth income considerably. The beneficiaries are the households with short or missing working hours. While full-time employed households, irrespective of the presence of children, arrive at a post-fisc income that is up to 7 percent higher than that of households with a middle work load, both categories fall short of the income attained by households with the fewest work hours.

Partly and early retired households clearly play a role in this somewhat surprising result, as indicated by the large benefits from pension plans to the ' $<50 \%$ ' category. On the other hand, households with short work hours, with and without children, are the main recipients of the benefits of the health, disability, unemployment, and accident insurance sectors, as well as social assistance. Moreover, households with few work hours receive the most educational services. This circumstance is brought about mainly by households with adult children in secondary and tertiary full-time education and less by single (parent) households whose members are working while completing their education. On the contribution side, it is noteworthy that both income and property taxes and social contributions hardly differ among households with long and middle work loads, and are clearly lower only for households with a small work load. 
Table 6: Incidence of Public Expenditures and Revenues by Work Load, Households in Working Age Group, 2005

\begin{tabular}{|c|c|c|c|c|c|c|c|}
\hline & $\begin{array}{l}\stackrel{\circ}{\circ} \\
\stackrel{\wedge}{\wedge}\end{array}$ & $\begin{array}{l}\stackrel{0}{0} \\
\stackrel{0}{0} \\
\stackrel{1}{n}\end{array}$ & $\begin{array}{l}\stackrel{0}{\circ} \\
\stackrel{n}{v}\end{array}$ & 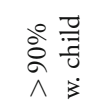 & 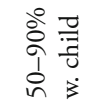 & 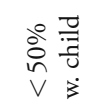 & 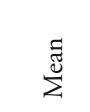 \\
\hline & \multicolumn{7}{|c|}{ per adult equivalent, in $\mathrm{CHF}$} \\
\hline Pre-fisc income & $\begin{array}{l}105,740 \\
(70,960)\end{array}$ & $\begin{array}{l}91,800 \\
(43,300)\end{array}$ & $\begin{array}{l}32,320 \\
(29,230)\end{array}$ & $\begin{array}{l}69,500 \\
(38,660)\end{array}$ & $\begin{array}{l}70,400 \\
(41,260)\end{array}$ & $\begin{array}{l}38,180 \\
(29,640)\end{array}$ & $\begin{array}{l}79,790 \\
(57,150)\end{array}$ \\
\hline Post-fisc income & $\begin{array}{l}65,890 \\
(38,410)\end{array}$ & $\begin{array}{l}62,710 \\
(26,800)\end{array}$ & $\begin{array}{l}71,980 \\
(33,620)\end{array}$ & $\begin{array}{l}62,320 \\
(28,450)\end{array}$ & $\begin{array}{l}58,300 \\
(28,870)\end{array}$ & $\begin{array}{l}66,050 \\
(45,510)\end{array}$ & $\begin{array}{l}63,650 \\
(33,270)\end{array}$ \\
\hline Public spending & 25,420 & 32,350 & 76,310 & 36,870 & 33,900 & 58,050 & 36,870 \\
\hline Public goods & 6,170 & 5,950 & 4,820 & 6,120 & 6,270 & 5,390 & 5,970 \\
\hline Education & 2,140 & 4,140 & 6,580 & 9,110 & 9,870 & 12,850 & 6,090 \\
\hline Culture & 970 & 950 & 880 & 880 & 780 & 640 & 890 \\
\hline Health & 2,480 & 2,920 & 2,940 & 2,950 & 2,940 & 3,000 & 2,800 \\
\hline Transport & 3,610 & 3,350 & 2,960 & 2,500 & 2,610 & 1,960 & 3,060 \\
\hline Subsidies & 1,570 & 580 & 400 & 4,790 & 450 & 300 & 1,220 \\
\hline Old-age ins. (AHV) benefits & 40 & 30 & 1,730 & 0 & 0 & 0 & 200 \\
\hline Pension plans & 560 & 1,660 & 19,910 & 70 & 90 & 2,460 & 2,790 \\
\hline Disability ins. (IV) benefits & 1,690 & 3,190 & 12,790 & 1,150 & 930 & 6,290 & 3,120 \\
\hline Health insurance benefits & 3,090 & 3,550 & 3,650 & 3,110 & 3,180 & 3,270 & 3,270 \\
\hline Other social insurance benefits & 2,090 & 3,730 & 12,020 & 4,210 & 4,510 & 8,990 & 4,590 \\
\hline Social assistance & 160 & 1,320 & 5,960 & 590 & 990 & 11,190 & 1,710 \\
\hline Debt service & 1,030 & 1,310 & 3,100 & 1,500 & 1,380 & 2,360 & 1,500 \\
\hline Public revenues & 65,260 & 61,450 & 36,650 & 44,050 & 46,000 & 30,180 & 53,020 \\
\hline Income and property taxes & 12,460 & 11,170 & 9,030 & 6,980 & 7,090 & 4,710 & 9,620 \\
\hline Earnings and capital taxes & 2,200 & 2,380 & 2,600 & 1,420 & 1,470 & 1,470 & 1,990 \\
\hline Excise duties & 6,180 & 5,790 & 5,120 & 4,540 & 4,440 & 3,730 & 5,290 \\
\hline Other taxes & 2,810 & 2,780 & 2,710 & 1,890 & 1,990 & 1,750 & 2,450 \\
\hline Remunerations & 5,260 & 5,070 & 4,100 & 5,210 & 5,340 & 4,590 & 5,090 \\
\hline Public investments & 3,020 & 2,840 & 2,460 & 2,090 & 2,120 & 1,700 & 2,550 \\
\hline Contrib. to AHV and IV & 8,650 & 7,530 & 3,080 & 5,900 & 5,780 & 2,940 & 6,600 \\
\hline Contrib. to pension plans & 11,400 & 11,120 & 2,240 & 6,950 & 8,020 & 3,430 & 8,730 \\
\hline Contrib. to health insurance & 2,810 & 3,220 & 3,150 & 2,710 & 2,740 & 2,570 & 2,890 \\
\hline
\end{tabular}


Table 6 continued

\begin{tabular}{|c|c|c|c|c|c|c|c|}
\hline & $\begin{array}{l}\stackrel{0}{\circ} \\
\stackrel{\circ}{\wedge}\end{array}$ & 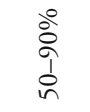 & $\begin{array}{l}\stackrel{0}{ } \\
\stackrel{n}{v}\end{array}$ & 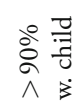 & 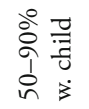 & 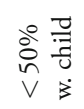 & $\stackrel{\Xi}{\Sigma}$ \\
\hline Contrib. to other social ins. & 4,920 & 4,170 & 960 & 2,910 & 3,090 & 1,550 & 3,550 \\
\hline \multirow[t]{3}{*}{ Capital income of social ins. } & 5,560 & 5,390 & 1,210 & 3,430 & 3,920 & 1,730 & 4,270 \\
\hline & $\begin{array}{l}\stackrel{\circ}{\circ} \\
\stackrel{\circ}{\wedge}\end{array}$ & 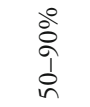 & $\begin{array}{l}\stackrel{0}{\circ} \\
\stackrel{n}{v}\end{array}$ & 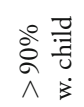 & 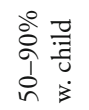 & 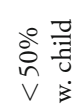 & $\sum_{\Sigma}^{\Xi}$ \\
\hline & \multicolumn{7}{|c|}{ in $\%$ of pre-fisc income } \\
\hline Pre-fisc income & 100.0 & 100.0 & 100.0 & 100.0 & 100.0 & 100.0 & 100.0 \\
\hline Post-fisc income & 62.3 & 68.3 & 222.7 & 89.7 & 82.8 & 173.0 & 79.8 \\
\hline Public spending & 24.0 & 35.2 & 236.1 & 53.1 & 48.2 & 152.1 & 46.2 \\
\hline Public goods & 5.8 & 6.5 & 14.9 & 8.8 & 8.9 & 14.1 & 7.5 \\
\hline Education & 2.0 & 4.5 & 20.3 & 13.1 & 14.0 & 33.7 & 7.6 \\
\hline Culture & 0.9 & 1.0 & 2.7 & 1.3 & 1.1 & 1.7 & 1.1 \\
\hline Health & 2.3 & 3.2 & 9.1 & 4.2 & 4.2 & 7.9 & 3.5 \\
\hline Transport & 3.4 & 3.7 & 9.1 & 3.6 & 3.7 & 5.1 & 3.8 \\
\hline Subsidies & 1.5 & 0.6 & 1.2 & 6.9 & 0.6 & 0.8 & 1.5 \\
\hline Old-age ins. (AHV) benefits & 0.0 & 0.0 & 5.4 & 0.0 & 0.0 & 0.0 & 0.3 \\
\hline Pension plans & 0.5 & 1.8 & 61.6 & 0.1 & 0.1 & 6.5 & 3.5 \\
\hline Disability ins. (IV) benefits & 1.6 & 3.5 & 39.6 & 1.7 & 1.3 & 16.5 & 3.9 \\
\hline Health insurance benefits & 2.9 & 3.9 & 11.3 & 4.5 & 4.5 & 8.6 & 4.1 \\
\hline Other social insurance benefits & 2.0 & 4.1 & 37.2 & 6.1 & 6.4 & 23.6 & 5.8 \\
\hline Social assistance & 0.2 & 1.4 & 18.4 & 0.8 & 1.4 & 29.3 & 2.1 \\
\hline Debt service & 1.0 & 1.4 & 9.6 & 2.2 & 2.0 & 6.2 & 1.9 \\
\hline
\end{tabular}


Table 6 continued

\begin{tabular}{|c|c|c|c|c|c|c|c|}
\hline & $\begin{array}{l}\stackrel{0}{\circ} \\
\stackrel{\wedge}{\wedge}\end{array}$ & 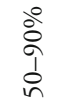 & $\begin{array}{l}\stackrel{0}{\circ} \\
\stackrel{n}{n} \\
v\end{array}$ & 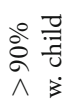 & 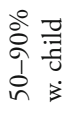 & 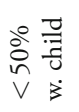 & $\stackrel{\Xi}{\Sigma}^{\Xi}$ \\
\hline & \multicolumn{7}{|c|}{ in $\%$ of pre-fisc income + benefits (real \& monetary) } \\
\hline Public revenues & 49.8 & 49.5 & 33.7 & 41.4 & 44.1 & 31.4 & 45.4 \\
\hline Income and property taxes & 9.5 & 9.0 & 8.3 & 6.6 & 6.8 & 4.9 & 8.2 \\
\hline Earnings and capital taxes & 1.7 & 1.9 & 2.4 & 1.3 & 1.4 & 1.5 & 1.7 \\
\hline Excise duties & 4.7 & 4.7 & 4.7 & 4.3 & 4.3 & 3.9 & 4.5 \\
\hline Other taxes & 2.1 & 2.2 & 2.5 & 1.8 & 1.9 & 1.8 & 2.1 \\
\hline Remunerations & 4.0 & 4.1 & 3.8 & 4.9 & 5.1 & 4.8 & 4.4 \\
\hline Public investments & 2.3 & 2.3 & 2.3 & 2.0 & 2.0 & 1.8 & 2.2 \\
\hline Contrib. to AHV and IV & 6.6 & 6.1 & 2.8 & 5.5 & 5.5 & 3.1 & 5.7 \\
\hline Contrib. to pension plans & 8.7 & 9.0 & 2.1 & 6.5 & 7.7 & 3.6 & 7.5 \\
\hline Contrib. to health insurance & 2.1 & 2.6 & 2.9 & 2.5 & 2.6 & 2.7 & 2.5 \\
\hline Contrib. to other social ins. & 3.8 & 3.4 & 0.9 & 2.7 & 3.0 & 1.6 & 3.0 \\
\hline Capital income of social ins. & 4.2 & 4.3 & 1.1 & 3.2 & 3.8 & 1.8 & 3.7 \\
\hline
\end{tabular}

Note: The allocation of public expenditures and revenues to households corresponds to the incidence assumptions of the standard scenario defined in Section 2 and Table 2. Figures in parentheses are standard errors.

To summarize, the vertical redistribution of resources across income categories is accompanied by the horizontal redistribution across socioeconomic groups. Within a year, considerable means flow from childless households to families with children. Households with middle to long work hours support households with little or no participation in the labor market at and before retirement age. Other horizontal redistributions across working and nonworking households that, even if not explicitly shown, emerge from the incidence figures occur due to disability, ill health and accident, motherhood, and unemployment. In general, household groups that would have to manage with far below-average income without state interventions clearly improve their economic situation thanks to the public transfers and sometimes attain even above-average post-fisc income. This situation begs the question as to what extent risks are not only sufficiently insured, but rather overinsured, and to what extent this situation leads to negative 
work and savings incentives. This circumstance is all the more acute because the income sacrifice is modest when a household switches from full-time occupation to a mid-level work load.

\subsection{Lifetime Income Before and After Transfers}

Figure 2 displays the average courses of pre- and post-fisc lifetime income that result if, as described in Section 2.3, average cohort income is generated out of available annual cross-sectional incidence analyses and the separate incomes are strung together according to cohort age. The pre-fisc income starts out low in the younger years and then rises to a first peak at around age 30. Afterwards, income declines during the years when many households start a family and the children are small, so that full-time employment often ceases. After age 40, income ascends again until it reaches the second peak between 50 and 55. With the gradual withdrawal from work, income then starts to decline again. Towards age 70 , the decline slows as the pre-fisc income usually no longer includes earned income and is generated mainly out of invested assets.

Public expenditures and revenues considerably smooth lifetime income. After the age of about 20, when employment is increasingly taken up and income rises, post-fisc income begins to depart from pre-fisc income. After age 30, a post-fisc income of about 55,000 francs is reached, a level that remains more or less constant until the age of 50. Compared to pre-fisc income, this amount is 20,000 to 25,000 francs less, but the kink in the family years evens out. After age 50, postfisc income, coupled with fewer family burdens and an increase in benefits that substitute for earned income (often disability or unemployment benefits prior to effective old-age benefits), begins to rise. Around the age of 60, post-fisc income surpasses pre-fisc income. Finally, due to the higher utilization of health and care services, post-fisc income possibly increases again between ages 70 and 75 .

The course of lifetime income before and after transfers shows that elderly households, on average, receive high positive net transfers. At the same time, considerable reductions of pre-fisc income during the working years indicate that the benefits in old age are generally pre-financed through negative net transfers. An increase in the (social security) contribution burden during the working life breaks the income peaks of that period. In return, this increase in contributions during the work phase helps avoid a drop in income after retirement; in fact, quite the reverse is true. On average, post-retirement income exceeds the income realized before the withdrawal from work. 
Figure 2: Average Course of Pre- and Post-Fisc Lifetime Income

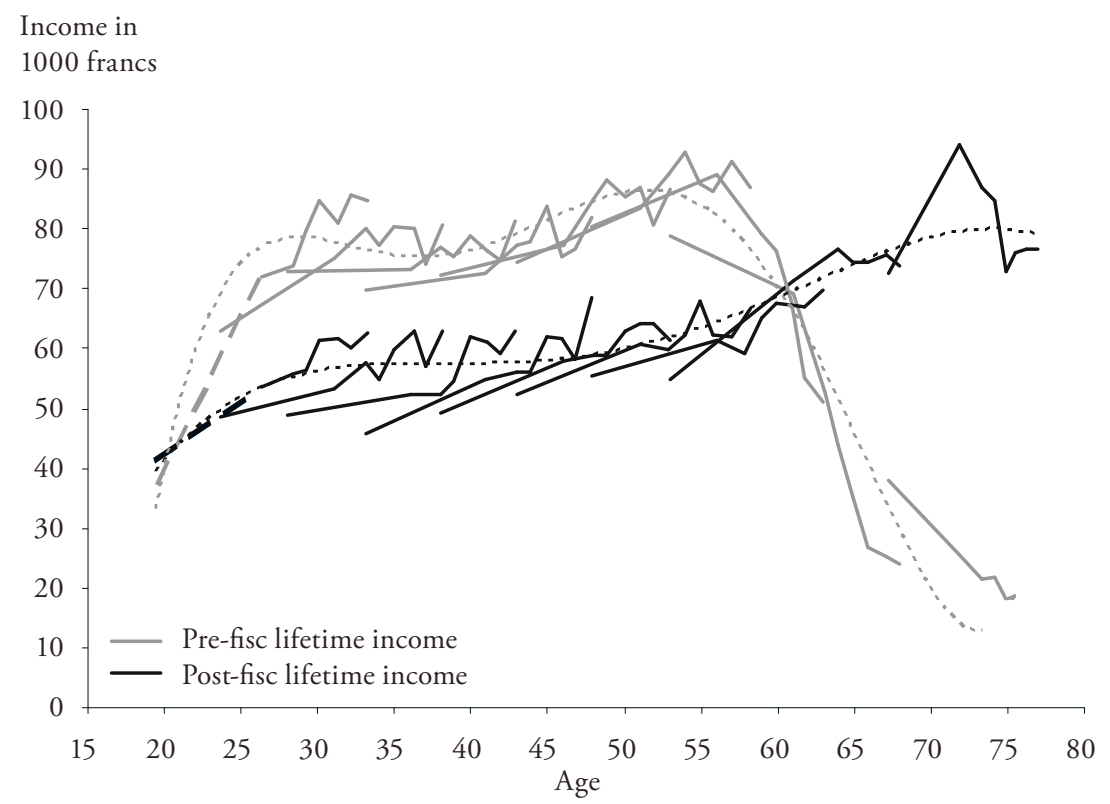

Note: Each part of the curve shows the average course of income per cohort as calculated in the annual analyses for 1990, 1998, 2000-05 (for detailed figures see Table 10 in the Appendix). Strung together, these parts approximate the average course of the lifetime income before and after transfers, respectively. The dotted lines represent the smoothing of the piecewise courses. Income is calculated in 2005 prices.

\subsection{Redistribution across Households versus Redistribution across Stages of Life}

Table 7 shows the inequality measure of the income of all households over all available years (pooled sample) and its decomposition into the inequality between and within cohorts or households. ${ }^{7}$ The first part of the table (p.138) shows, under the title $I_{\alpha}^{\text {Total }}$, the inequality measures of pre-fisc and post-fisc income as well as income after the provision of single benefits and contributions aggregates. The percentages represent the changes of $I_{\alpha}^{\text {Total }}$ in comparison to the prefisc situation. Under the titles $I_{\alpha}^{\text {Between }}$ and $I_{\alpha}^{\text {Within }}$, the inequality measures of the income aggregates are separated into inequalities between and within cohorts,

7 Cohorts are approximations of individual households, see Section 2.3. 
Table 7: Transfer-Induced Change in Measured Inequality within and between Cohort Income, Period 1990-2005

\begin{tabular}{|c|c|c|c|c|c|c|c|c|c|}
\hline & & $\alpha=0$ & & & $\alpha=1$ & & & $\alpha=2$ & \\
\hline & & & Sign. & & & Sign & & & Sign. \\
\hline$I_{\alpha}^{\text {Total }}$ & & & & & & & & & \\
\hline Pre-fisc income & 1.056 & & & 0.297 & & & 0.372 & & \\
\hline $\begin{array}{l}\text { Pre-fisc income + real } \\
\text { benefits }\end{array}$ & 0.192 & $-81.8 \%$ & $* *$ & 0.182 & $-38.6 \%$ & $* *$ & 0.248 & $-33.4 \%$ & $* *$ \\
\hline $\begin{array}{l}\text { Pre-fisc income }+ \text { social } \\
\text { benefits }\end{array}$ & 0.125 & $-88.2 \%$ & $* *$ & 0.135 & $-54.5 \%$ & $* *$ & 0.198 & $-46.8 \%$ & $* *$ \\
\hline Pre-fisc income-taxes & 1.306 & $23.7 \%$ & $* *$ & 0.416 & $39.9 \%$ & $* *$ & 0.471 & $26.7 \%$ & ** \\
\hline $\begin{array}{l}\text { Pre-fisc income-social } \\
\text { contributions }\end{array}$ & 0.875 & $-17.1 \%$ & $* *$ & 0.338 & $13.6 \%$ & $* *$ & 0.505 & $35.8 \%$ & $* *$ \\
\hline Post-fisc income & 0.152 & $-85.6 \%$ & ** & 0.143 & $-51.8 \%$ & $* *$ & 0.213 & $-42.6 \%$ & $* *$ \\
\hline$I_{\alpha}^{\text {Between }}$ & & & & & & & & & \\
\hline Pre-fisc income & 0.060 & & & 0.048 & & & 0.041 & & \\
\hline $\begin{array}{l}\text { Pre-fisc income }+ \text { real } \\
\text { benefits }\end{array}$ & 0.031 & $-2.7 \%$ & . & 0.027 & $-7.1 \%$ & . & 0.024 & $-4.4 \%$ & . \\
\hline $\begin{array}{l}\text { Pre-fisc income }+ \text { social } \\
\text { benefits }\end{array}$ & 0.002 & $-5.5 \%$ & & 0.002 & $-15.5 \%$ & & 0.002 & $-10.4 \%$ & \\
\hline Pre-fisc income-taxes & 0.119 & $5.6 \%$ & . & 0.085 & $12.5 \%$ & . & 0.067 & $7.1 \%$ & . \\
\hline $\begin{array}{l}\text { Pre-fisc income-social } \\
\text { contributions }\end{array}$ & 0.046 & $-1.3 \%$ & . & 0.038 & $-3.3 \%$ & . & 0.033 & $-2.0 \%$ & . \\
\hline Post-fisc income & 0.010 & $-4.7 \%$ & . & 0.010 & $-12.8 \%$ & . & 0.011 & $-8.0 \%$ & . \\
\hline$I_{\alpha}^{W i t h i n}$ & & & & & & & & & \\
\hline Pre-fisc income & 0.996 & & & 0.249 & & & 0.331 & & \\
\hline $\begin{array}{l}\text { Pre-fisc income + real } \\
\text { benefits }\end{array}$ & 0.161 & $-79.1 \%$ & $* *$ & 0.155 & $-31.6 \%$ & $* *$ & 0.224 & $-28.9 \%$ & ** \\
\hline $\begin{array}{l}\text { Pre-fisc income }+ \text { social } \\
\text { benefits }\end{array}$ & 0.123 & $-82.7 \%$ & $* *$ & 0.133 & $-39.0 \%$ & $* *$ & 0.196 & $-36.4 \%$ & $* *$ \\
\hline Pre-fisc income-taxes & 1.187 & $18.1 \%$ & $* *$ & 0.331 & $27.5 \%$ & $* *$ & 0.404 & $19.6 \%$ & ** \\
\hline $\begin{array}{l}\text { Pre-fisc income-social } \\
\text { contributions }\end{array}$ & 0.829 & $-15.8 \%$ & $* *$ & 0.299 & $16.9 \%$ & $* *$ & 0.472 & $37.7 \%$ & $* *$ \\
\hline Post-fisc income & 0.142 & $-80.9 \%$ & $* *$ & 0.133 & $-39.1 \%$ & $* *$ & 0.203 & $-34.6 \%$ & ** \\
\hline
\end{tabular}


Table 7 continued

\begin{tabular}{|c|c|c|c|c|c|c|c|c|c|}
\hline & \multicolumn{3}{|c|}{$\alpha=0$} & \multicolumn{3}{|c|}{$\alpha=1$} & \multicolumn{3}{|c|}{$\alpha=2$} \\
\hline \multicolumn{10}{|l|}{$I_{\alpha}^{\text {Total }}$} \\
\hline Pre-fisc income + benefits & 0.091 & & & 0.104 & & & 0.154 & & \\
\hline $\begin{array}{l}\text { Pre-fisc income + benefits } \\
\text { - taxes }\end{array}$ & 0.095 & $4.5 \%$ & $* *$ & 0.103 & $-1.7 \%$ & . & 0.145 & $-5.7 \%$ & $*$ \\
\hline $\begin{array}{l}\text { Pre-fisc income }+ \text { benefits } \\
\text {-income/property taxes }\end{array}$ & 0.085 & $-6.9 \%$ & ** & 0.096 & $-7.7 \%$ & ** & 0.141 & $-8.8 \%$ & ** \\
\hline $\begin{array}{l}\text { Pre-fisc income + benefits } \\
\text {-social contrib. }\end{array}$ & 0.110 & $20.4 \%$ & $* *$ & 0.122 & $16.6 \%$ & ** & 0.191 & $24.0 \%$ & $* *$ \\
\hline $\begin{array}{l}\text { Pre-fisc income + benefits } \\
\text { - social contrib. } \\
\text { excl. health ins. }\end{array}$ & 0.106 & $16.0 \%$ & $* *$ & 0.118 & $13.0 \%$ & ** & 0.185 & $19.7 \%$ & ** \\
\hline \multicolumn{10}{|l|}{$I_{\alpha}^{\text {Between }}$} \\
\hline Pre-fisc income + benefits & 0.001 & & . & 0.001 & & & 0.001 & & \\
\hline $\begin{array}{l}\text { Pre-fisc income + benefits } \\
\text { - taxes }\end{array}$ & 0.001 & $-0.4 \%$ & . & 0.001 & $-0.4 \%$ & . & 0.001 & $-0.3 \%$ & . \\
\hline $\begin{array}{l}\text { Pre-fisc income }+ \text { benefits } \\
\text {-income/property taxes }\end{array}$ & 0.001 & $-0.3 \%$ & $*$ & 0.001 & $-0.4 \%$ & $*$ & 0.001 & $-0.3 \%$ & * \\
\hline $\begin{array}{l}\text { Pre-fisc income } \\
+ \text { benefit s-social contrib. }\end{array}$ & 0.006 & $5.0 \%$ & . & 0.006 & $4.4 \%$ & . & 0.006 & $3.1 \%$ & . \\
\hline $\begin{array}{l}\text { Pre-fisc income + benefits } \\
\text {-social contrib. } \\
\text { excl. health ins. }\end{array}$ & 0.006 & $5.1 \%$ & . & 0.006 & $4.2 \%$ & . & 0.006 & $3.0 \%$ & . \\
\hline \multicolumn{10}{|l|}{$I_{\alpha}^{W i t h i n}$} \\
\hline Pre-fisc income + benefits & 0.090 & & & 0.103 & & & 0.153 & & \\
\hline $\begin{array}{l}\text { Pre-fisc income + benefits } \\
\text { - taxes }\end{array}$ & 0.094 & $5.0 \%$ & $* *$ & 0.102 & $-1.3 \%$ & & 0.144 & $-5.5 \%$ & $*$ \\
\hline $\begin{array}{l}\text { Pre-fisc income + benefits } \\
\text {-income/property taxes }\end{array}$ & 0.084 & $-6.6 \%$ & $* *$ & 0.096 & $-7.3 \%$ & $* *$ & 0.140 & $-8.5 \%$ & ** \\
\hline $\begin{array}{l}\text { Pre-fisc income + benefits } \\
\text {-social contrib. }\end{array}$ & 0.104 & $15.5 \%$ & $* *$ & 0.116 & $12.2 \%$ & $* *$ & 0.185 & $20.9 \%$ & ** \\
\hline $\begin{array}{l}\text { Pre-fisc income + benefits } \\
\text {-social contrib. } \\
\text { excl. health ins. }\end{array}$ & 0.100 & $11.0 \%$ & $* *$ & 0.112 & $8.8 \%$ & ** & 0.179 & $16.7 \%$ & $* *$ \\
\hline
\end{tabular}




\section{Table 7 continued}

Note: $I_{\alpha}^{\text {Total }}$ shows the total inequality of different income aggregates across all households over all available observation years (pooled sample) by means of the generalized entropy measure. The percentages show for each income aggregate the change of $I_{\alpha}^{\text {Total }}$ compared to the pre-fisc income situation (first part of the table on p.138) or the situation after benefits (second part of the table on p. 139). $I_{\alpha}^{\text {Between }}$ and $I_{\alpha}^{\text {Within }}$ show which part of the total inequality traces back to the inequality between and within cohorts, respectively. The percentages given under $I_{\alpha}^{\text {Between }}$ and $I_{\alpha}^{\text {Within }}$ show which proportion of the percentage change of $I_{\alpha}^{\text {Total }}$ is attributable to these two components. ${ }^{* *} / * /$. in the 'Sign.' column represent significant changes on a 0.01/0.05/0.10 level determined in nonparametric bootstrap tests with 1000 resamples. The aggregate 'real benefits' includes all the expenditureside positions of the state budget (see Table 0 ), except for the benefits of social insurance and the other social welfare institutions. These two positions are subsumed in the 'social benefits' aggregate. 'Taxes' include all revenue-side positions of the state budget, except for social security contributions and capital and other revenues of social insurance. These positions are pooled in the 'social contributions' aggregate.

respectively. There, the percentages show which proportion of the change of $I_{\alpha}^{\text {Total }}$ is derived from these two components. Additionally, for the contribution aggregates, the second part of Table 7 (p. 139) shows the results of these computations, if the sum of pre-fisc income and benefits is used as the reference base instead of pre-fisc income alone.

The decomposition of the inequality measures of pre-fisc income shows that, before transfers, the general inequality in the population is induced primarily by inequalities across different stages of life within households. For example, in the case of $\alpha=0$, the entire income inequality of 1.056 consists of 0.996 of income inequalities within cohorts $\left(I_{\alpha}^{\text {Within }}\right)$ and only of 0.060 of inequalities between long-term (1990 to 2005) cohort income $\left(I_{\alpha}^{\text {Between }}\right)$. Given that the cohorts are approximations of individual households, this finding indicates that pre-fisc income inequalities are attributable primarily to age-specific or life stage-specific income variations within households and less to differences in long-term income across households.

The public transfer system tends to further reduce the differences between long-term household income. This scenario follows from the $I_{\alpha}^{\text {Between }}$ of the postfisc income distribution, which, for all values of $\alpha$, is smaller than the $I_{\alpha}^{\text {Between }}$ of the pre-fisc situation. Much more relevant, however, is the strong and highly significant decrease in the inequality within the households. In the case of $\alpha=0$, the entire decline of $I_{\alpha}^{\text {Total }}$ of 85.6 percent is 80.9 percentage points caused by the decline of $I_{\alpha}^{\text {Within }}$, and only 4.7 percentage points caused by the decline of $I_{\alpha}^{\text {Between }}$. 
For $\alpha=1$ and $\alpha=2$, the dominance of the reduction of $I_{\alpha}^{\text {Within }}$ is less pronounced, but still very clear. These results provide strong evidence that, in the long run, public interventions first smooth individual lifetime income and only in the second instance level out income differences across households.

The breakdown into individual interventions shows that real public services and goods induce a certain convergence of long-term income across households, but significantly smooth income over time. The monetary social benefits, in the long run, have no leveling effect at all across households; however, they provoke even more significant intra-household income shifts across the life course. Taxes, in their entirety, do not have a noticeable effect on inter-household income differences, if they are related to the broader reference base of pre-fisc income and benefits (shown in the second part of Table 7 on p. 139). However, taxes intensify the income fluctuations in the life course for low-income households and smooth the lifetime income only for upper-income households. Hence, the effects of income and property taxes, which smooth the lifetime income over the whole income spectrum, are offset.

Social security contributions are the only transfer category that tends to enhance the differences between cohorts and across long-term household income. In the case of $\alpha=0$, for instance, social contributions increase the inequality of the combined pre-fisc and benefit income by 20.4 percent (second part of Table 7). With the (weakly significant) 5.0 percentage points, the rise in $I_{\alpha}^{\text {Between }}$ contributes a fourth to this increase. This finding becomes more substantive if health insurance premiums are omitted. In fact, the cause of the greater interhousehold differences is more likely found in the strong alignment of other social security contributions with earned income. As a consequence, funding social insurance tends to burden low-income households relatively more than highincome households, because household income consists less of capital income, which is mainly exempted from contributions.

To summarize, the state, through its interventions, brings about a social balance across households with different long-term income potential. More effective, however, is the state's contribution to the smoothing of individual income fluctuations across life stages and its guarantee of a certain living standard in all life situations. Therefore, of primary importance is maintaining income after oldage withdrawal from work, but also during temporary, labor market-, health-, or family-related limitations of earning capacity. This focus on the insurance function comes to the fore particularly in a social security system in which social balance is of secondary importance. 


\section{Discussion}

\subsection{Cross-Comparison with Previous Evidence}

The first assessments of public redistribution by means of budget incidence analysis date from the 1970s and 1980s (e.g. Reynolds and SMolensky, 1977, for the United States; Meerman, 1979, for Malaysia; Gillespie, 1980, for Canada; LE GRAND, 1982, for the United Kingdom). Focusing on the annual redistribution, the general conclusion is that the state substantially redistributes income, whereby the combined redistributive effects of public expenditures exceed those of public revenues. More recent studies (see BoADway and KeEN, 2000) as well as the present paper confirm this finding.

Based on tax data for 1980, the as yet sole budget incidence study for Switzerland, conducted by Leu, Frey, and Buhmann (1988), appeared. ${ }^{8}$ Consistent with the results of this study, Leu et al. conclude that the state redistributes primarily through spending on social welfare. On the public revenue side, although they found a slight leveling effect of the whole contribution system, Leu et al. located progressive effects mainly from income and property taxes and identified indirect taxes as neutral to regressive.

The neutrality of the contribution system in today's results is in line with developments over the past 25 years. First, the introduction of the value-added tax led to a shift to indirect, consumption-based taxes, which burden low-income households relatively more than high-income households. Second, social security contributions rose with the general enactment of the occupational pension system and increased the contribution burden of those households whose income consists primarily of earned income and less of noncontributory capital income. Moreover, through the possibility of above-compulsory contributions, the introduction of the occupational pension system opened tax saving opportunities for the middle and upper income groups. Incidence studies in the international literature report similar developments, and mostly conclude that the tax incidence is roughly proportional to income (for an overview see Fullerton and Metcalf, 2002).

Empirical evidence concerning the state's redistributive impact over a whole life cycle is still rare, but compatible with the present paper. An early attempt to estimate lifetime tax incidence was made by Davies, St.-Hilaire, and Whalley (1984) for Canada. They found that both the progressivity of direct income taxes

8 Hauser, Bänziger, and Stebler (1994) provided a limited actualization in the $1990 \mathrm{~s}$ as they recalculated the results from Leu et al. for four income examples for middle-class households. 
and the regressivity of other taxes diminished in a life income perspective. As a consequence, the entire tax system, also in the long-term view, does not entail a leveling effect across households. Fullerton and Metcalf (2002) reconfirmed this finding for the United States. Nelissen (1998) shows for the Netherlands that the significance of inter-household redistribution induced by the social security system fades when calculated for a life cycle instead of single years.

Björklund and Palme (2002), finally, seem to have delivered the only redistribution analysis so far that decomposes total redistribution into inter- and intra-household components. They used panel data to analyze the redistributive impacts of Swedish social security benefits and income taxes. In accordance with this study, they conclude that the social benefits first smooth individual lifetime income and only secondarily level out inter-household income differences. In addition, deviating from this analysis, they found that income taxes bring about a significant inter-household redistribution as well.

\subsection{Limitations of the Analysis}

Although the present paper fits well into the existing literature, careful interpretation warrants the consideration of several constraints. First, like all incidence analyses, this study is restricted to the redistributive effects of interventions that have an impact on the national budget. Redistributive effects that follow from other state activities, such as price regulations or monetary policies, are not captured (RugGeri, 2003). Excluded as well is intergenerational redistribution, which is provoked by budget deficits or unsustainable funding and payout schemes in old-age provisions.

The second limitation is that the constructed pre-fisc income does not adjust for behavioral aspects of households in reaction to changes in public action. This factor gives rise to downward or upward biases in the estimates of the distributional impacts, depending on whether the absence of the state would induce more or less private income generation. In addition, the allocation of nonmonetary benefits and indirect contributions to households in most cases must be carried out on the basis of rather rough criteria. Whereas the use of alternative scenarios allows for the inclusion of further incidence assumptions, this study can only approximate the benefits and burdens for individual households. At least, sensitivity analyses show that the results are robust for a wide range of incidence assumptions.

Third, particularly when drawing political conclusions, it must be taken into account that budget incidence studies calculate average and not marginal redistributive effects. Therefore, they often give only indications as to which impacts 
accrue when a certain public intervention is further promoted or withdrawn (vAN DE WALLE, 1996). In addition, budget incidence analysis ignores second-round effects (Ruggeri, 2003). For example, even though low-income households are not the main beneficiaries of the spending for tertiary education, they can benefit indirectly if the improved qualifications of the working population positively affect the general economic development.

Fourth, incidence analysis incorporates public expenditures that yield benefits only in later years, such as the realization of large transportation infrastructure projects. In this case, the allocation of the expenditures happens at the wrong time, distorting the effective benefits of households upwards (AARON and McGuire, 1970). Similarly, the actual benefits of infrastructure facilities are underestimated if they were constructed in the past. As a consequence, the explanatory power of budget incidence analysis is generally better for those public services that are generated for the most part through running expenses so that the yearly costs and benefits are closer together. Such services include education and health.

Finally, budget incidence studies are limited to the level of the purchasing power and do not conduct a benefit analysis in a welfare-theoretical sense. For example, they assume that the value of a public service for a household can be identified adequately by its provision costs. Clearly, the benefit that a household effectively derives can deviate from these costs (VAN DE WALLE, 1996).

\section{Summary and Conclusion}

This paper examines the state-induced redistribution of income in Switzerland using the instrument of budget incidence analysis. It studies redistribution in relation to annual household income as well as from a long-term perspective in relation to lifetime income. The results can be summarized as follows:

1. The state, together with social security institutions, has a substantial redistributive impact. As a consequence, income differences in the population are strongly reduced.

2. In contrast to the annual perspective, however, a long-term view shows that the leveling of income is not caused primarily by the balance across households, but by the state-prescribed income transfers across different stages of life within households to smooth their lifetime income.

3 . As evident from the average course of lifetime income pre- and post-transfers, the increased contribution burden during the work stages of life levels out 
income peaks. In return, this situation prevents income drops in times of limited or missing earning capacity, especially in old age.

4. The redistributive effects arise mainly from public expenditures. Within a year, both monetary social benefits and, to a lesser extent, real services and goods bolster low income. From a long-term perspective, household-internal income smoothing over the life cycle has the largest impact, but the real benefits still have a small leveling effect across households.

5. The tax system in its entirety, neither from the short- nor long-term view, brings about redistribution across households. Although income and property taxes are progressive, they are neutralized by the opposite effects of other taxes. In the long run, taxes, above all for well-off households, contribute to the smoothing of lifetime income.

6. Social security contributions have a regressive effect from an annual as well as long-term perspective and tend to increase inter-household inequalities. The reason lies with the strong alignment of social contributions with earned income, which disproportionately charges households that have little noncontributory capital income.

7. The vertical redistribution across income groups is accompanied by horizontal resource transfers from working to retired households, childless households to families, and working-age individuals with a high work load to those with a smaller one.

Today, public debate on redistribution is often polarized. Whereas one side deplores the "desolidarization" and the dismantling of the welfare system, the other complains of the rampant growth of the social state. Neither of these views adequately reflects today's situation. An objective analysis shows that household income is insured against the expected and unexpected vicissitudes of life. At the same time, most of the beneficiaries receive support and services that they had paid for earlier on in life. Hence, the benefits are for the most part rendered and claimed by the whole population. Beyond that, as part of social equalization, households with poor income prospects receive resources they have not prefunded themselves. Despite the often differing rhetoric, these transfers have good target accuracy and generally reach the lowest-income households.

Contributions to state and social insurance institutions, costing 54 percent of the economic output, have undoubtedly reached an unprecedented dimension. Unsurpassed as well, however, is the level of public goods and services provided to individual citizens. It may be that the immediate contribution burden is more perceptible than the benefits, which often come as real goods taken for granted or old-age entitlements that are remunerative only in the future. However, if 
the extent of the effective and potential benefits is taken into consideration, the high contributions can well be interpreted as the price for a high equivalent or the premium for a high insurance sum. Therefore, if the contribution burden is judged as too high, then the publicly guaranteed living standard has to be questioned as well.

This chapter shows that the average income of retired households regularly exceeds the income of working ones. This issue raises the question as to whether the state induces an overinsurance of income risks. Even if contributions and benefits largely even out in the long run, this outcome is accompanied by a limited freedom of households to define their lifetime income course. From such a point of view, an expansion of the welfare state is less a question of redistributing income by favoring certain household categories and burdening others, but a question of increasingly inhibiting households in their autonomy of decisionmaking.

\section{Appendix}

\section{A. Incidence Assumptions}

\section{A.1 Revenue Incidence Assumptions}

With regard to tax incidence, the general consensus for personal income and property taxes is that no shifting takes place and the formal tax debtor is also the effective taxpayer. Therefore, public revenues from these taxes are distributed among households according to their income and property taxes paid.

No such consensus exists for corporate taxes, however. One literature camp considers the capital owners as the payers of these taxes, because companies distribute profits only after taxes. The other camp attributes the tax burden to the consumers because companies can roll off their taxes by raising product prices. This analysis takes a middle position and allocates half of the earnings and capital taxes on capital owners (approximated by the capital income of the households) and half on consumers. For real estate taxes, where a similar disagreement exists, the same approach applies: 50 percent of the tax burden is allocated to the real estate owners according to their real estate taxes paid, and 50 percent to the tenants according to their rent expenses. In the progressive scenario, the corporate and real estate taxes shift entirely to the capital and real estate owners, respectively. In the regressive case, the consumers fully bear the corporate taxes. 
The standard assumption with regard to excise duties is that they are shifted to consumers via higher prices. Accordingly, value-added taxes, fuel taxes, taxes on tobacco products, as well as vehicle taxes, customs duties, royalties and concessions are distributed in proportion to the (specific) consumption expenditures of the households. However, the progressive scenario allows for price increases to regularly induce wage adjustments and social transfers so that the excise duties should be assigned to household income instead.

For remunerations, two positions are considered as well. One reflects the view that remunerations compensate the state for providing its services and are therefore borne equally by the individuals in each household. The other position implies that the well-off populace more frequently makes use of chargeable services and also is more likely to buy more expensive services (e.g., in the old-age and nursing home sector which fees constitute an important part of the remunerations). Again, the standard scenario adopted in this analysis represents the middle ground and allocates remunerations one half each according to the size and income of the households. The alternative scenarios adopt the extreme positions.

Social security fees are attributed entirely to the insurants proportional to their contributions. This arrangement reflects the common understanding that the employers' contributions are an implicit part of salaries. The capital revenues of the social insurance system, which are accumulated mostly by the occupational benefit institutions, are thought of as indirect contributions and therefore are distributed among households according to paid contributions as well. This arrangement reflects the opinion that, in the absence of pension plans, capital gains would be garnered privately and could be used at liberty. Similarly, the public financial and investment income is charged according to taxes paid, because, in the end, the necessary funds must be procured by the taxpayer.

\section{A.2 Expenditure Incidence Assumptions}

On the side of public expenditures, a distinction must first be made between public goods in the economic sense and goods or services that are publicly provided but privately used. The former includes, for example, the general administration, national security, or involvement in international affairs. The allocation of expenses for these typically generally accessible, nonrivaling goods is not evident. Incidence analysis often employs the concept of allocation per capita, which is based on the conventional assumption of the collective goods theory whereby everybody benefits equally from public goods. Apart from this, public goods are also assigned according to household income, thereby assuming that 
they benefit those who participate in economic production and rely on a functioning business context. The standard scenario apportions the public goods one half each according to household size and income, whereas the progressive and regressive variants again take the extreme positions.

For privately consumed public services, identification of the beneficiaries is easier. In the case of public transport services, road facilities, or subsidized cultural institutions, private outlays are necessary in order to benefit from the stateprovided goods. The allocation of these services can then be oriented towards specific household expenses. Other services do not require a cost participation, but the recipients of the benefits are identifiable. This scenario applies directly to the education sector where public expenditures can be assigned according to the number of students per household. In the case of the health sector, the costs are allocable according to the age-gender profiles of the household, because these profiles determine the utilization of health care services.

The allocation of monetary benefits rests upon the hypothesis that the recipient of a payment equals the effective beneficiary. Social insurance and social assistance are thus assigned proportionally to the transfers received. For agricultural subsidies, it is assumed that they, in the form of direct payments or production grants, stay with the farmers. Accordingly, their allocation is based on farming income. The remaining subsidies are distributed according to household consumption expenditures, assuming that they lead to price reductions.

Finally, the expenses required to serve the national debt, in the standard scenario, are apportioned to households according to the public expenditures assigned to the households up to that point. This arrangement reflects the view that the public debt favors mainly those who also receive the most benefits from the state. Departing from this arrangement, the regressive scenario takes the position that debt service benefits the owners of government securities and thus allocates the debt interests according to capital income. 


\section{B. Additional Tables}

Table 8: Key Figures of Pre- and Post-Fisc Income Distributions, Working-Age Households, 2005

\begin{tabular}{|c|c|c|c|}
\hline (in CHF) & Pre-fisc income & Post-fisc income & Net transfer \\
\hline Variance & $3.27 \mathrm{E}+09$ & $1.11 \mathrm{E}+09$ & \\
\hline Mean & 79,795 & 63,645 & \\
\hline Median & 72,903 & 57,527 & \\
\hline First quintile & 42,925 & 42,727 & \\
\hline \multicolumn{4}{|c|}{ Av. income per pre-fisc decile } \\
\hline 1 & 12,100 & 66,800 & 54,700 \\
\hline 2 & 35,700 & 53,700 & 18,000 \\
\hline 3 & 49,000 & 53,600 & 4,600 \\
\hline 4 & 58,800 & 51,600 & $-7,200$ \\
\hline 5 & 67,500 & 54,000 & $-13,500$ \\
\hline 6 & 77,500 & 56,000 & $-21,500$ \\
\hline 7 & 87,600 & 60,500 & $-27,100$ \\
\hline 8 & 100,500 & 64,900 & $-35,600$ \\
\hline 9 & 119,800 & 70,000 & $-49,800$ \\
\hline 10 & 189,800 & 105,300 & $-84,500$ \\
\hline
\end{tabular}


Table 9: Transfer-Induced Change in Measured Inequality, 2005

\begin{tabular}{|c|c|c|c|c|c|c|c|c|c|}
\hline & $I_{\alpha=0}$ & $\Delta$ & Sign. & $I_{\alpha=1}$ & $\Delta$ & Sign. & $I_{\alpha=2}$ & $\Delta$ & Sign. \\
\hline Pre-fisc income & 0.765 & & & 0.306 & & & 0.364 & & \\
\hline $\begin{array}{l}\text { Pre-fisc income } \\
+ \text { real benefits }\end{array}$ & 0.202 & $-74 \%$ & $* *$ & 0.185 & $-40 \%$ & ** & 0.232 & $-36 \%$ & ** \\
\hline $\begin{array}{l}\text { Pre-fisc income } \\
+ \text { social benefits }\end{array}$ & 0.109 & $-86 \%$ & $* *$ & 0.118 & $-61 \%$ & ** & 0.164 & $-55 \%$ & ** \\
\hline Pre-fisc income-taxes & 1.439 & $88 \%$ & $* *$ & 0.433 & $42 \%$ & $* *$ & 0.423 & $16 \%$ & \\
\hline $\begin{array}{l}\text { Pre-fisc income } \\
\text {-social contributions }\end{array}$ & 0.865 & $13 \%$ & * & 0.345 & $13 \%$ & ** & 0.471 & $30 \%$ & ** \\
\hline Post-fisc income & 0.107 & $-86 \%$ & $* *$ & 0.100 & $-67 \%$ & ** & 0.128 & $-65 \%$ & ** \\
\hline Pre-fisc income + benefits & 0.079 & & & 0.088 & & & 0.121 & & \\
\hline Pre-fisc inc. + benef. - taxes & 0.080 & $2 \%$ & & 0.082 & $-7 \%$ & & 0.101 & $-16 \%$ & . \\
\hline $\begin{array}{l}\text { Pre-fisc inc. + benef. } \\
\text {-income \& property taxes }\end{array}$ & 0.069 & $-12 \%$ & $* *$ & 0.076 & $-14 \%$ & ** & 0.096 & $-21 \%$ & ** \\
\hline $\begin{array}{l}\text { Pre-fisc inc. + benef. } \\
\text {-social contributions }\end{array}$ & 0.086 & $9 \%$ & $* *$ & 0.097 & $10 \%$ & ** & 0.141 & $16 \%$ & $* *$ \\
\hline $\begin{array}{l}\text { Pre-fisc inc. + benef. } \\
\text { - social contrib. excl. } \\
\text { health ins. }\end{array}$ & 0.081 & $3 \%$ & & 0.092 & $4 \%$ & ** & 0.133 & $10 \%$ & $* *$ \\
\hline
\end{tabular}

Note: This table shows different general entropy measures for the distribution of the main income aggregates. $\alpha=0$ reflects the highest sensitivity to inequalities in the low-income households. The " $\Delta$ " column in the upper part of the table shows the change in the inequality measure compared to the income situation before any transfer. The lower part of the table presents the change in the inequality measure in comparison to the income situation after the positive, but before the negative, transfers. ${ }^{* *} / * /$. in the 'Sign.' column represent significant changes on a $0.01 / 0.05 / 0.10$ level determined in nonparametric bootstrap tests with 1000 resamples. The aggregate 'real benefits' includes all the expenditure-side positions of the state budget (see Table 1), except for the benefits of social insurance and the other social welfare institutions. These two positions are subsumed in the 'social benefits' aggregate. 'Taxes' include all revenue-side positions of the state budget, except for social security contributions and capital and other revenues of social insurance. These positions are pooled in the 'social contributions' aggregate. 
Table 10: Pseudo Panel of Pre- and Post-Fisc Income, 1990-2005

\begin{tabular}{|c|c|c|c|c|c|c|}
\hline $\begin{array}{l}\text { Age } \\
\text { group }\end{array}$ & Cohort & & 1990 & 1998 & 2000 & 2001 \\
\hline-1934 & $\mathrm{C} 1$ & $\begin{array}{l}\text { Average age } \\
\text { Pre-fisc income } \\
\text { Post-fisc income } \\
\text { No. of observations }\end{array}$ & $\begin{array}{c}67.2 \\
38,120 \\
72,500 \\
3,047\end{array}$ & $\begin{array}{c}71.8 \\
25,480 \\
94,140 \\
1,428\end{array}$ & $\begin{array}{r}73.3 \\
21,390 \\
86,840 \\
517\end{array}$ & $\begin{array}{r}74.1 \\
21,800 \\
84,580 \\
576\end{array}$ \\
\hline 1935-39 & $\mathrm{C} 2$ & $\begin{array}{l}\text { Average age } \\
\text { Pre-fisc income } \\
\text { Post-fisc income } \\
\text { No. of observations }\end{array}$ & $\begin{array}{r}53.0 \\
78,830 \\
54,940 \\
834\end{array}$ & $\begin{array}{l}61.0 \\
69,280 \\
71,450 \\
537\end{array}$ & $\begin{array}{r}63.1 \\
52,730 \\
74,990 \\
241\end{array}$ & $\begin{array}{r}63.9 \\
44,030 \\
76,770 \\
253\end{array}$ \\
\hline $1940-44$ & C3 & $\begin{array}{l}\text { Average age } \\
\text { Pre-fisc income } \\
\text { Post-fisc income } \\
\text { No. of observations }\end{array}$ & $\begin{array}{c}47.9 \\
80,330 \\
55,330 \\
1,103\end{array}$ & $\begin{array}{l}56.0 \\
89,040 \\
61,230 \\
690\end{array}$ & $\begin{array}{c}57.9 \\
82,990 \\
59,100 \\
298\end{array}$ & $\begin{array}{r}58.9 \\
79,010 \\
65,090 \\
305\end{array}$ \\
\hline $1945-49$ & $\mathrm{C} 4$ & $\begin{array}{l}\text { Average age } \\
\text { Pre-fisc income } \\
\text { Post-fisc income } \\
\text { No. of observations }\end{array}$ & $\begin{array}{c}43.0 \\
74,350 \\
52,410 \\
1,331\end{array}$ & $\begin{array}{l}51.0 \\
83,640 \\
60,800 \\
858\end{array}$ & $\begin{array}{l}52.9 \\
89,030 \\
59,680 \\
332\end{array}$ & $\begin{array}{r}53.9 \\
92,820 \\
62,450 \\
352\end{array}$ \\
\hline $1950-54$ & C5 & $\begin{array}{l}\text { Average age } \\
\text { Pre-fisc income } \\
\text { Post-fisc income } \\
\text { No. of observations }\end{array}$ & $\begin{array}{l}38.0 \\
72,350 \\
49,160 \\
1,395\end{array}$ & $\begin{array}{c}46.0 \\
77,200 \\
57,910 \\
886\end{array}$ & $\begin{array}{c}48.0 \\
85,120 \\
58,940 \\
384\end{array}$ & $\begin{array}{r}48.8 \\
88,190 \\
58,990 \\
379\end{array}$ \\
\hline $1955-59$ & C6 & $\begin{array}{l}\text { Average age } \\
\text { Pre-fisc income } \\
\text { Post-fisc income } \\
\text { No. of observations }\end{array}$ & $\begin{array}{l}33.1 \\
69,740 \\
45,950 \\
1,482\end{array}$ & $\begin{array}{c}40.9 \\
72,720 \\
54,770 \\
1,157\end{array}$ & $\begin{array}{c}43.0 \\
77,120 \\
56,140 \\
433\end{array}$ & $\begin{array}{r}43.9 \\
78,010 \\
56,180 \\
456\end{array}$ \\
\hline 1960-64 & C7 & $\begin{array}{l}\text { Average age } \\
\text { Pre-fisc income } \\
\text { Post-fisc income } \\
\text { No. of observations }\end{array}$ & $\begin{array}{r}28.0 \\
72,800 \\
48,830 \\
1,416\end{array}$ & $\begin{array}{c}36.0 \\
73,220 \\
52,390 \\
1,308\end{array}$ & $\begin{array}{r}38.0 \\
76,920 \\
52,440 \\
480\end{array}$ & $\begin{array}{l}38.9 \\
75,370 \\
54,410 \\
486\end{array}$ \\
\hline $1965-69$ & $\mathrm{C} 8$ & $\begin{array}{l}\text { Average age } \\
\text { Pre-fisc income } \\
\text { Post-fisc income } \\
\text { No. of observations }\end{array}$ & $\begin{array}{l}23.7 \\
62,970 \\
48,610 \\
635\end{array}$ & $\begin{array}{c}31.1 \\
74,960 \\
53,330 \\
1,188\end{array}$ & $\begin{array}{c}33.1 \\
80,080 \\
57,570 \\
469\end{array}$ & $\begin{array}{r}34.0 \\
77,400 \\
54,820 \\
444\end{array}$ \\
\hline $1970-74$ & C9 & $\begin{array}{l}\text { Average age } \\
\text { Pre-fisc income } \\
\text { Post-fisc income } \\
\text { No. of observations }\end{array}$ & $\begin{array}{r}19.5 \\
37,570 \\
41,500 \\
23\end{array}$ & $\begin{array}{r}26.3 \\
71,830 \\
53,470 \\
780\end{array}$ & $\begin{array}{r}28.4 \\
73,860 \\
55,720 \\
301\end{array}$ & $\begin{array}{l}29.3 \\
79,700 \\
56,260 \\
291\end{array}$ \\
\hline
\end{tabular}


Table 10 continued

\begin{tabular}{|c|c|c|c|c|c|c|}
\hline $\begin{array}{l}\text { Age } \\
\text { group }\end{array}$ & Cohort & & 2002 & 2003 & 2004 & 2005 \\
\hline-1934 & $\mathrm{C} 1$ & $\begin{array}{l}\text { Average age } \\
\text { Pre-fisc income } \\
\text { Post-fisc income } \\
\text { No. of observations }\end{array}$ & $\begin{array}{r}74.9 \\
18,050 \\
72,790 \\
508\end{array}$ & $\begin{array}{r}75.5 \\
18,660 \\
76,030 \\
443\end{array}$ & $\begin{array}{r}76.2 \\
18,550 \\
76,590 \\
380\end{array}$ & $\begin{array}{r}76.9 \\
19,190 \\
76,730 \\
324\end{array}$ \\
\hline $1935-39$ & $\mathrm{C} 2$ & $\begin{array}{l}\text { Average age } \\
\text { Pre-fisc income } \\
\text { Post-fisc income } \\
\text { No. of observations }\end{array}$ & $\begin{array}{r}64.9 \\
35,060 \\
74,470 \\
265\end{array}$ & $\begin{array}{r}65.9 \\
26,660 \\
74,320 \\
229\end{array}$ & $\begin{array}{r}67.1 \\
25,190 \\
75,550 \\
204\end{array}$ & $\begin{array}{r}67.9 \\
24,030 \\
73,760 \\
196\end{array}$ \\
\hline $1940-44$ & C3 & $\begin{array}{l}\text { Average age } \\
\text { Pre-fisc income } \\
\text { Post-fisc income } \\
\text { No. of observations }\end{array}$ & $\begin{array}{c}59.9 \\
76,380 \\
67,630 \\
287\end{array}$ & $\begin{array}{r}60.9 \\
68,030 \\
67,280 \\
307\end{array}$ & $\begin{array}{r}61.7 \\
55,060 \\
67,110 \\
234\end{array}$ & $\begin{array}{r}63.0 \\
51,090 \\
69,750 \\
260\end{array}$ \\
\hline $1945-49$ & $\mathrm{C} 4$ & $\begin{array}{l}\text { Average age } \\
\text { Pre-fisc income } \\
\text { Post-fisc income } \\
\text { No. of observations }\end{array}$ & $\begin{array}{r}54.9 \\
87,690 \\
67,900 \\
350\end{array}$ & $\begin{array}{c}55.8 \\
86,430 \\
62,340 \\
340\end{array}$ & $\begin{array}{c}57.0 \\
91,240 \\
61,920 \\
299\end{array}$ & $\begin{array}{r}58.2 \\
87,020 \\
66,740 \\
270\end{array}$ \\
\hline $1950-54$ & C5 & $\begin{array}{l}\text { Average age } \\
\text { Pre-fisc income } \\
\text { Post-fisc income } \\
\text { No. of observations }\end{array}$ & $\begin{array}{r}50.1 \\
85,230 \\
62,930 \\
363\end{array}$ & $\begin{array}{c}51.0 \\
86,860 \\
64,040 \\
364\end{array}$ & $\begin{array}{l}51.9 \\
80,630 \\
64,270 \\
340\end{array}$ & $\begin{array}{r}53.0 \\
86,500 \\
61,420 \\
247\end{array}$ \\
\hline $1955-59$ & C6 & $\begin{array}{l}\text { Average age } \\
\text { Pre-fisc income } \\
\text { Post-fisc income } \\
\text { No. of observations }\end{array}$ & $\begin{array}{r}45.0 \\
83,820 \\
62,120 \\
448\end{array}$ & $\begin{array}{r}45.9 \\
75,530 \\
61,650 \\
377\end{array}$ & $\begin{array}{r}46.8 \\
76,600 \\
58,350 \\
381\end{array}$ & $\begin{array}{r}47.9 \\
82,020 \\
68,620 \\
334\end{array}$ \\
\hline 1960-64 & C7 & $\begin{array}{l}\text { Average age } \\
\text { Pre-fisc income } \\
\text { Post-fisc income } \\
\text { No. of observations }\end{array}$ & $\begin{array}{r}40.0 \\
78,670 \\
61,900 \\
510\end{array}$ & $\begin{array}{r}41.0 \\
76,420 \\
61,050 \\
477\end{array}$ & $\begin{array}{c}41.9 \\
74,710 \\
59,260 \\
400\end{array}$ & $\begin{array}{r}42.9 \\
81,220 \\
62,860 \\
372\end{array}$ \\
\hline $1965-69$ & $\mathrm{C} 8$ & $\begin{array}{l}\text { Average age } \\
\text { Pre-fisc income } \\
\text { Post-fisc income } \\
\text { No. of observations }\end{array}$ & $\begin{array}{r}35.0 \\
80,340 \\
59,880 \\
486\end{array}$ & $\begin{array}{r}36.3 \\
79,910 \\
62,890 \\
447\end{array}$ & $\begin{array}{r}37.0 \\
74,180 \\
57,020 \\
408\end{array}$ & $\begin{array}{r}38.1 \\
80,700 \\
62,810 \\
411\end{array}$ \\
\hline $1970-74$ & C9 & $\begin{array}{l}\text { Average age } \\
\text { Pre-fisc income } \\
\text { Post-fisc income } \\
\text { No. of observations }\end{array}$ & $\begin{array}{r}30.1 \\
84,800 \\
61,400 \\
292\end{array}$ & $\begin{array}{r}31.3 \\
81,010 \\
61,760 \\
279\end{array}$ & $\begin{array}{r}32.2 \\
85,650 \\
60,210 \\
290\end{array}$ & $\begin{array}{l}33.3 \\
84,790 \\
62,560 \\
289\end{array}$ \\
\hline
\end{tabular}

Note: The table shows the pseudo panel for nine age group cohorts generated out of the budget incidence analyses from 1990, 1998, and 2000 to 2005 . For each observational year and for each 


\section{Table 10 continued}

cohort, it shows the average age as well as the average pre- and post-fisc income. Income is calculated in prices of the year 2005. The income development between 1990 and 2005 within a single cohort represents the income development of an individual household of the same period.

\section{References}

Aaron, Henry, and Martin McGuire (1970), "Public Goods and Income Distribution”, Econometrica, 38 (6), pp.907-920.

Atrinson, Anthony B., Lee Rainwater and Timothy M. Smeeding (1995), "Income Distribution in OECD Countries: Evidence from the Luxembourg Income Study", Social Policy Studies, no. 18, OECD.

Björklund, Anders, and Marten Palme (2002), "Income Redistribution within the Life Cycle Versus between Individuals: Emprical Evidence Using Swedish Panel Data", in: Daniel Cohen, Thomas Piketty and Gilles SaintPaul (eds), The Economics of Rising Inequalities, Oxford, pp. 205-224.

Boadway, Robin, and Michael Keen (2000), "Redistribution", in: Anthony B. Atkinson and François Bourguignon (eds), Handbook of Income Distribution, vol. 1, Amsterdam.

Browning, Martin, Angus Deaton, and Margaret Irish (1985), "A Profitable Approach to Labor Supply and Commodity Demands over the LifeCycle", Econometrica, 53 (3), pp. 503-544.

Cowell, Frank A. (1984), “The Structure of American Income Inequality”, Review of Income and Wealth, 30, pp. 351-75.

Davies, James, France St.-Hilaire, and John Whalley (1984), "Some Calculations of Lifetime Tax Incidence”, American Economic Review, 74, pp. 633-649.

Deaton, Angus (1985), "Panel Data from Time Series of Cross-Sections", Journal of Econometrics, 30, pp. 109-126.

Economiesuisse (2007), Wer finanziert den Staat in der Schweiz?, Zurich.

Ecoplan (2004), „Verteilung des Wohlstands in der Schweiz“, Bericht in Erfüllung des Postulates Fehr vom 9. Mai 2001 (01.3246), Eidgenössische Steuerverwaltung.

Falter, Jean-Marc (2006), "Equivalence Scales and Subjective Data in Switzerland", Swiss Journal of Economics and Statistics, 142 (2), pp. 263-284.

Federal Finance Administration, FFA (1990-2005), Ausgaben und Einnahmen von Bund, Kantonen und Gemeinden nach Funktionen, Berne. 
Federal Social Insurance Office, FSIO (1990-2005), Swiss Social Insurance Statistics, Berne.

Fullerton, Don, and Gilbert E. Metcalf (2002), "Tax Incidence”, in: A. J. Auerbach and M. Feldstein (eds), Handbook of Public Economics, vol. 4, Amsterdam, pp. 1787-1872.

Gillespie, W. Irwin (1980), The Redistribution of Income in Canada, Ottawa.

Hauser, Martin, Annik Bänziger, and Sabine Stebler (1994), „Budgetinzidenz: Wie wird der Mittelstand betroffen?", Pilot Study, Schweizerische Kader-Organisation.

Künzi, Kilian, and Markus Schärrer (2004), Wer zahlt für die Soziale Sicherheit und wer profitiert davon? Eine Analyse der Sozialtransfers in der Schweiz, Zurich.

Le Grand, Julien (1982), The Strategy of Equality: Redistribution and the Social Services, London.

Leu, Robert. E., René L. Frey, and Brigitte Buhmann (1988), „Budgetinzidenz: Wer profitiert von den öffentlichen Leistungen und wer zahlt dafür?“, in: René L. Frey and Robert E. Leu (eds), Der Sozialstaat unter der Lupe. Wohlstandsverteilung und Wohlstandsumverteilung in der Schweiz, Basel, pp. 149-174.

Meerman, Jacob (1979), Public Expenditures in Malaysia: Who Benefits and Why?, New York.

Nelissen, Jan H. M. (1998), "Annual Versus Lifetime Income Redistribution by Social Security", Journal of Public Economics, 68, pp. 223-249.

Reynolds, Morgan O., and Eugene Smolensky (1977), Public Expenditures, Taxes, and the Distribution of Income: The United States, 1950, 1961, 1970, New York.

Ruggeri, Giuseppe C. (2003), "Public Expenditure Incidence Analysis", in: Anwar Shah (ed.), Bringing Civility in Governance, Handbook on Public Sector Performance Reviews, vol.3, World Bank, chapter 1.

Suter, Christian, and Marie-Claire Mathey (2000), „Wirksamkeit und Umverteilungseffekte staatlicher Sozialleistungen“, info:social 3:00, Swiss Federal Statistical Office.

van de Walle, Dominique (1996), "Assessing the Welfare Impacts of Public Spending”, Policy Research Working Paper, no. 1670, World Bank.

Verbeek, Marno, and Theo Nijman (1992), "Can Cohort Data be Treated as Genuine Panel Data?”, Empirical Economics, 17 (1), pp.9-23. 


\section{SUMMARY}

Using the example of Switzerland, this paper examines the extent to which the state and the social security institutions change the income distribution. Two sets of questions are examined: (1) Who benefits from the public services, and who bears the public costs? (2) To what extent does an annual redistribution involve redistribution (a) across households with different lifetime income, and (b) across different phases of life within the same households? Budget incidence analyses and pseudo panel procedures allow to compare annual and lifetime household incomes that arise before and after transfers. The results suggest that public interventions induce substantial redistribution, which is due primarily, however, to income-smoothing transfers within households and not to redistribution across households. 